ata. 37

2. To: (Receiving Organization)

Distribution

5. Proj./Prog./Dept./Div.:

$W-465$

8. Originator Remarks:

Systems Engineering Management and Implementation Plan for

Project $W-465$, Immobilized Low-Activity Waste Storage

11. Receiver.Remarks: ..... 11A... Design. Basel ine Document?.... [X] Yes [] No
3. From: (Originating Organization) Immobilized Waste

6. Design Authority/ Design Agent/Cog. Engr.: C. A. Petersen/D. A. Burbank
4. Related EDT No.:

$\mathrm{N} / \mathrm{A}$

7. Purchase Order No.:

$N / A$
9. Equip./Component No.: $\mathrm{N} / \mathrm{A}$

10. System/Bldg./Faci.lity: $N / A$

12. Major Assm. Dwg. No.: $N / A$

13. Permit/Permit Application No.: $N / A$

14. Required Response Date: $\mathrm{N} / \mathrm{A}$

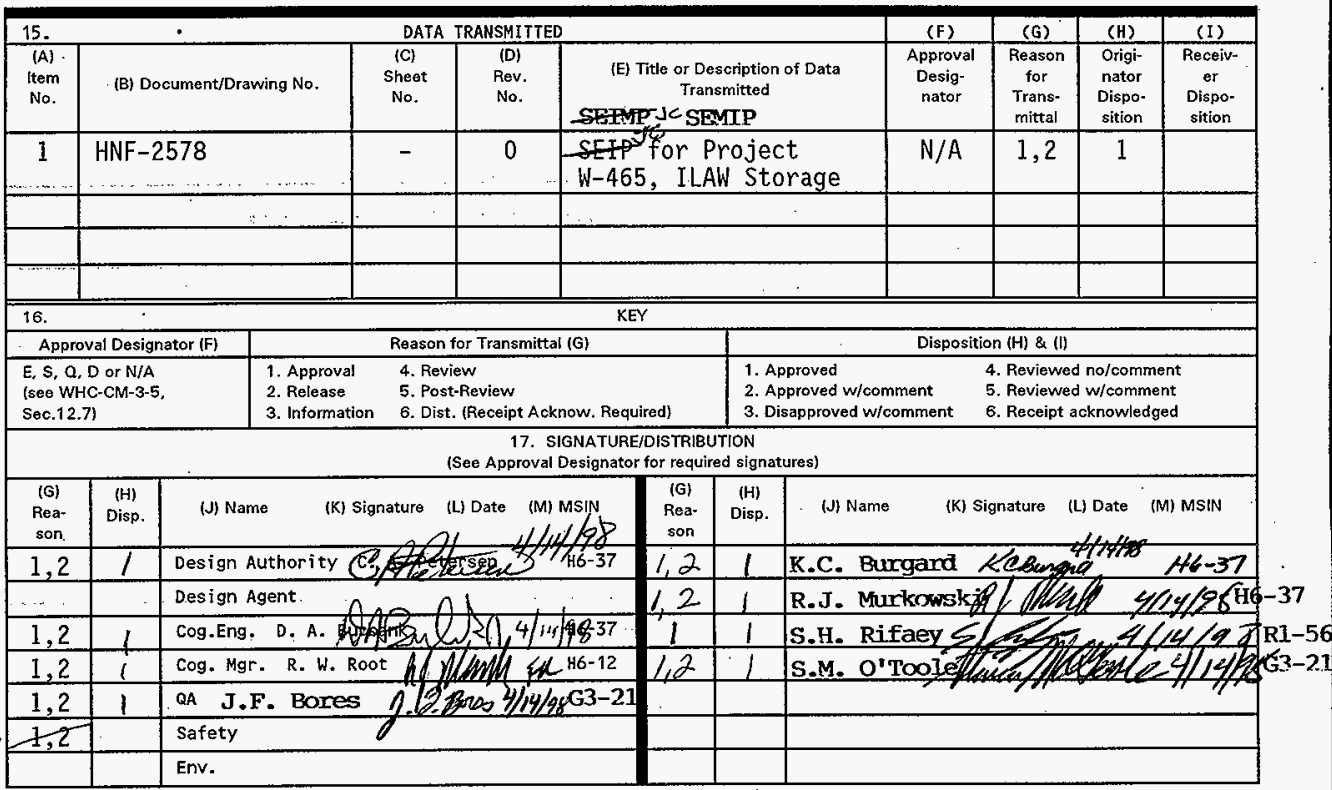

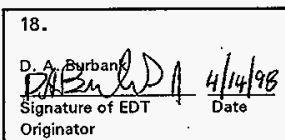

19.

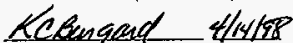

Authorized Fepresentative Date for Receiving Organization
20.

20

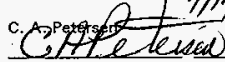

Design Authority/ Cognizant Manager
21. DOE APPROVAL (if requi red)

Ctrl. No.

[] Approved

[] Approved $w /$ comments

[] D isapproved $w /$ comments 


\section{SYSTEMS ENGINEERING MANAGEMENT AND IMPLEMENTATION PLAN FOR PROJECT W-465, IMMOBILIZED LOW-ACTIVITY WASTE STORAGE}

J. R. Kasper and D. A. LaTray

Parsons Infrastructure and Technology Group, Inc., Richland, WA U.S. Department of Energy Contract DE-AC06-96RL13200

EDT/ECN: $621690 \quad$ UC: 2000

Org Code: $73400 \quad$ Charge Code: D2D01

B\&R Code: EW3130010 Total Pages: $-49-46$

Key Words: SEMP, Systems engineering, implementation plan, technical baseline, Immobilized Low-Activity Waste (ILAW), Immobilized High-Leve] Waste (IHLW), waste storage, TWRS storage and disposal projects

Abstract: The Systems Engineering Management and Implementation P1an (SEMIP) for TWRS Project W-465 describes the project implementation of the Tank Waste Remediation System Systems Engineering Management Plan (TWRS SEMP), Rev. I. The SEMIP out lines systems engineering (SE) products and processes to be used by the project for technical baseline development. A formal graded approach is used to determine the products necessary for requirements, design, and operational baseline completion. SE management processes are defined, and roles and responsibilities for management processes and major technical baseline elements are documented.

TRADEMARK.DISCLAIMER. Reference herein to any specific commercial product, process, or service by trade name, trademark, manufacturer, or otherwise, does not necessarily constitute or imply its endorsement, recommendation, of favoring by the United States Government or any agency thereof or its contractors or subcontractors.

Printed in the United States of America. To obtain copies of this document, contact: Document Control Services, P.0. Box 950, Mailstop H6-08, Richland WA 99352, Phone (509) 372-2420; Fax (509) 376-4989.
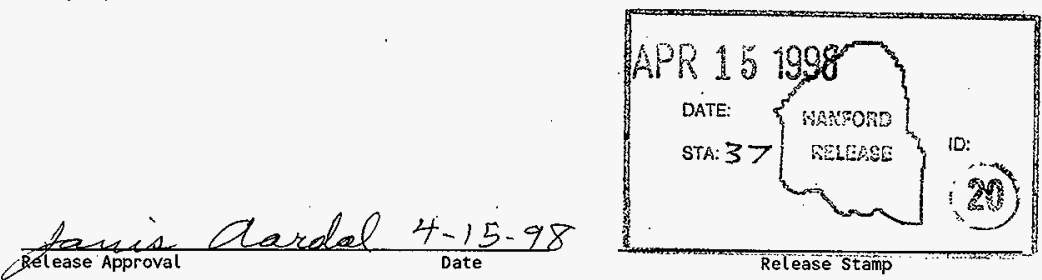

\section{Approved for Public Release}


Systems Engineering Management and Implementation Plan for

Project W-465, Immobilized Low-Activity Waste Storage

HNF-2578, Rev. 0 
HNF-2578, Rev. 0

\section{TABLE OF CONTENTS}

List of Acronyms and Abbreviations $\ldots \ldots \ldots \ldots \ldots \ldots \ldots \ldots \ldots \ldots \ldots \ldots \ldots \ldots \ldots$ iv

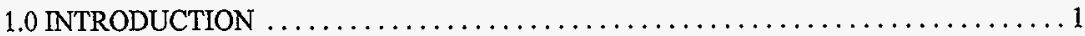

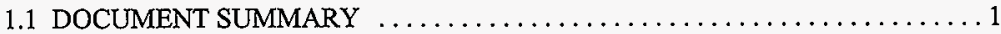

1.2 SCOPE AND APPLICABILITY $\ldots \ldots \ldots \ldots \ldots \ldots \ldots \ldots \ldots \ldots \ldots \ldots \ldots \ldots$

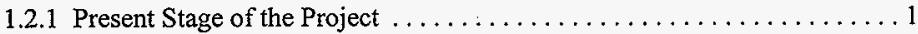

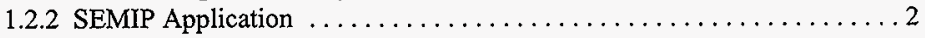

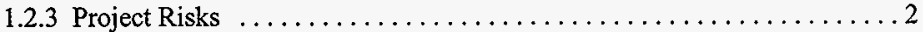

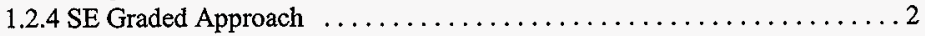

1.2.5 Interface With Other Planning Documents $\ldots \ldots \ldots \ldots \ldots \ldots \ldots \ldots$

2.0 SYSTEMS ENGINEERING MANAGEMENT PROCESSES $\ldots \ldots \ldots \ldots \ldots \ldots \ldots .5$

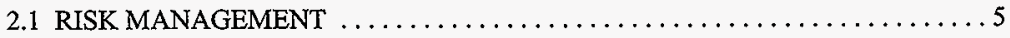

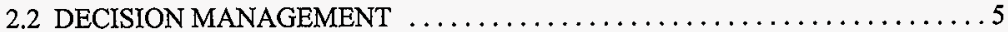

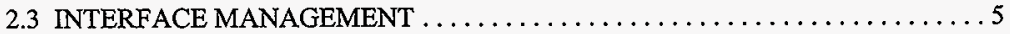

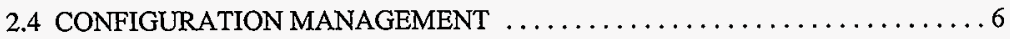

2.5 TECHNICAL REVIEWS . ............................. 6

2.6 SE MANAGEMENT PROCESS ROLES AND RESPONSIBILITIES $\ldots \ldots \ldots .8$

Table 2.1. Management Processes Responsibilities Matrix ........... 8

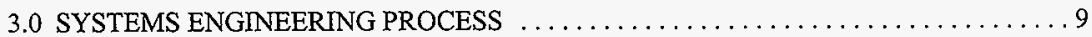

3.1 SYSTEMS ENGINEERING APPLICATION TO PROJECT W-465 ........9

3.1.1 Requirements Traceability . . . . . . . . . . . . . . . . . . . . 9

3.1 .2 Mission Analysis ................................ 9

3.1.3 Functions and Requirements/Specification Development ..........9

3.1.4 Alternative Analysis and Selection . . . . . . . . . . . . . . . . 10

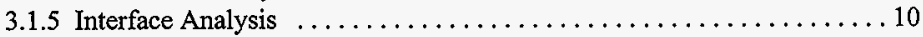

3.1.6 Interface Control Documentation ...................... 10

3.1.6.1 Privatization Contractor Interfaces $\ldots \ldots \ldots \ldots \ldots \ldots \ldots \ldots \ldots \ldots \ldots$

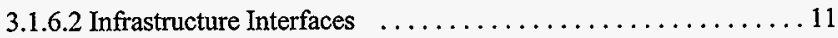

3.1.6.3 Environmental Interface ....................... 11

3.1.6.4 Secondary Waste Interface $\ldots \ldots \ldots \ldots \ldots \ldots \ldots \ldots \ldots \ldots \ldots$

3.1.6.5 Interface with Other TWRS Projects . . . . . . . . . . . . 11

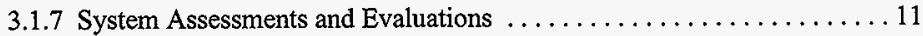

3.1.8 Specialty Engineering Analysis and Integration $\ldots \ldots \ldots \ldots \ldots \ldots 12$

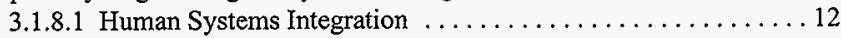

3.1.8.2 Reliability, Availability, and Maintainability (RAM) . . . . . 12

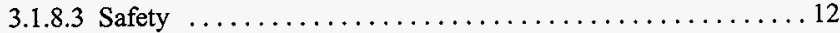

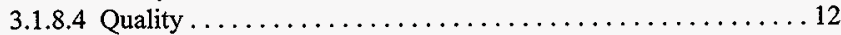

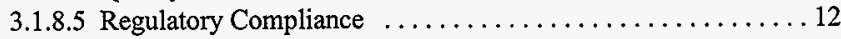

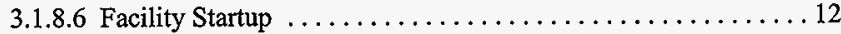

3.1.8.7 ILAW Performance Assessment . . . . . . . . . . . . . . 13

3.1.9 Operations and Maintenance Concept Development $\ldots \ldots \ldots \ldots \ldots \ldots 13$ 


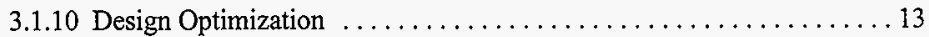

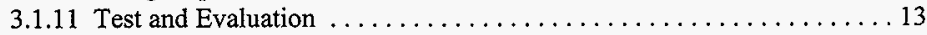

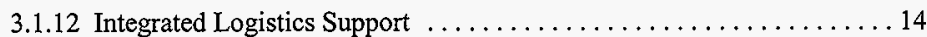

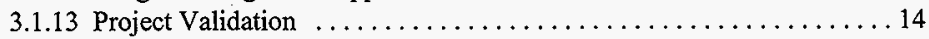

3.1.14 Decision Points . .............................. 14

3.2 TECHNICAL BASELINE DEVELOPMENT $\ldots \ldots \ldots \ldots \ldots \ldots \ldots \ldots \ldots \ldots$

Figure 3.1 Project W-465 Baseline Development Flow Diagram . . . . . . 16

3.3 MAJOR TECHNICAL BASELINE PRODUCTS ................... 19

Table 3.1. SE Processes/Products Required for Baseline Development . . . . . . 19

3.4 BASELINE PRODUCT ROLES AND RESPONSIBILITIES $\ldots \ldots \ldots \ldots \ldots 25$

Table 3.2. Roles and Responsibilities Matrix ....................

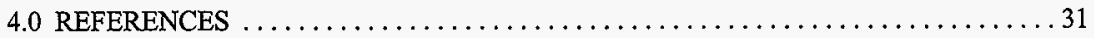

APPENDIX A - PROJECT W-465 SE GRADED ASSESSMENT TABLES .......... A-1

Table A.1. SE Graded Assessment of ILAW Vaults and Equipment .......... A-2

Table A.2. SE Graded Assessment of ILAW Transport and Packaging Systems ... A-5 
HNF-2578, Rev. 0

\section{LIST OF ACRONYMS}

$\begin{array}{ll}\text { AGA } & \text { Alternatives Generation and Analysis } \\ \text { CDR } & \text { Conceptual Design Report } \\ \text { CMIP } & \text { Configuration Management Implementation Plan } \\ \text { DRD } & \text { Design Requirements Document } \\ \text { EQS } & \text { Environmental, Quality, Safety } \\ \text { F\&Rs } & \text { Functions and Requirements } \\ \text { FSAR } & \text { Final Safety Analysis Report } \\ \text { HSTD } & \text { Hanford Site Technical Database } \\ \text { ICD } & \text { Interface Control Document } \\ \text { ILAW } & \text { Immobilized Low-Activity Waste } \\ \text { IP } & \text { Implementation Plan } \\ \text { JMN } & \text { Justification of Mission Need } \\ \text { LERF } & \text { Liquid Effluent Retention Facility } \\ \text { LMHC } & \text { Lockheed Martin Hanford Company } \\ \text { LMSI } & \text { Lockheed Martin Services, Inc. } \\ \text { MAR } & \text { Mission Analysis Report } \\ \text { MEL } & \text { Master Equipment List } \\ \text { MOA } & \text { Memorandum of Agreement } \\ \text { NRC } & \text { Nuclear Regulatory Commission } \\ \text { O\&M } & \text { Operations and Maintenance } \\ \text { OUP } & \text { Operations and Utilization Plan } \\ \text { P\&IDs } & \text { Piping and instrumentation diagrams } \\ \text { PA } & \text { Performance Assessment } \\ \text { PC } & \text { Private Contractor } \\ \text { PHMC } & \text { Project Hanford Management Contractor } \\ \text { PSE } & \text { Preliminary Safety Evaluation } \\ \text { QA } & \text { Quality Assurance } \\ \text { QAPP } & \text { Quality Assurance Program Plan } \\ \text { QC } & \text { Quality Control } \\ \text { RAM } & \text { Reliability, Availability, and Maintainability } \\ \text { RCRA } & \text { Resource Conservation and Recovery Act of 1976 } \\ \text { RML } & \text { Risk Management List } \\ \text { SARP } & \text { Safety Analysis Report for Packaging } \\ \text { SE } & \text { Systems Engineering } \\ \text { SEL } & \text { Safety Equipment List } \\ \text { SEMP } & \text { Systems Engineering Management Plan } \\ \text { SEMIP } & \text { Systems Engineering Management and Implementation Plan } \\ \text { SSC } & \text { systems, structures, and components } \\ \text { T\&E } & \text { Test and Evaluation } \\ \text { TEDF } & \text { Treated Effluent Disposal Facility } \\ \text { THI } & \text { Transportation Hazard Indicator } \\ \text { TWRS } & \text { Tank Waste Remediation Plan } \\ & \end{array}$




\subsection{INTRODUCTION}

\subsection{DOCUMENT SUMMARY}

This Systems Engineering Management and Implementation Plan (SEMIP) describes the Project W-465 (herein called the Project) implementation of the Tank Waste Remediation System Systems Engineering Management Plan (TWRS SEMP) (LMHC 1998a). The Project SEMIP defines the systems engineering (SE) products and processes used by the Project to comply with the TWRS SEMP (LMHC 1998a). It provides the basis for tailoring the SE processes by applying a graded approach to identify the minimum (necessary and sufficient) SE requirements for successful project execution without incurring unacceptable risks. The SEMIP is a living document that will be revised as necessary to reflect changes in systems engineering guidance as the Project evolves.

\subsection{SCOPE AND APPLICABILITY}

This project is a sub-project of the Storage and Disposal Program performed by the Tank Waste Retrieval (TWR) Division of Lockheed Martin Hanford Company's (LMHC) Tank Waste Remediation System (TWRS). A two-phase approach is being implemented at the Hanford Site to immobilize and interim store low-activity and high-level waste currently stored in underground tanks. The first step is a proof-of-concept effort to demonstrate the feasibility of using private contractors (PCs) to treat tank waste. Demonstration phase production of Immobilized Low Activity Waste (ILAW) is planned to begin in June 2002 and to be complete in 2007. The primary objectives of the W-465 Project are to design and construct a facility to provide initial ILAW storage space, provision of shipping containers, transport of ILAW to the facility, ILAW package handling for emplacement in the storage/disposal space, and monitoring of the stored waste. The general facility concept involves modifying existing vault facilities in the 200 East Area of the Hanford Site, as described in the Alternatives Generation and Analysis Report for Immobilized Low-Level Waste Interim Storage Architecture (WHC 1996a). Closure of the W-465 facility is beyond the scope of the Project, and will be completed following the operational period. Further details of the TWRS mission and background are given in the Tank Waste Remediation System Program Plan (FDH 1998e) and the Tank Waste Remediation System Mission Analysis Report (LMHC 1998b).

\subsubsection{Present Stage of the Project}

The W-465 Project is currently in the final stages of concept development with performance requirements identified and estimates prepared for completing the design and construction phases. The Project Justification of Mission Need (Piper 1996) has been completed, the Project "birthright" has been established in the Design Requirements Document (DRD) (SESC 1997), and Critical Decisionl (Authorization to initiate conceptual design) has been granted DOE-RL (DOE-RL 1996c). Major technical baseline products which have been completed include ILAW storage functions and requirements definition (WHC 1995a), the Alternatives Generation and 
Analysis Report for Immobilized Low-Level Waste Interim Storage Architecture (WHC 1996a), the Design Requirements Document for Project W-465 (Rev. 0, SESC 1997, and Rev. 1, SESC 1998a), and the Immobilized Low-Activity Waste Interim Storage Facility Project W-465 Conceptual Design Report (FDNW 1997a). Thus, the requirements baseline, as described in the TWRS SEMP, is nearly complete for the Project.

An independent assessment of SE processes and existing baseline products was completed in March, 1998. The assessment (Parsons 1998a) evaluated the adequacy of the technical baseline through the Conceptual Design Report (CDR) (FDNW 1997a), and provided recommendations for $\mathrm{SE}$ process improvements. The assessment concluded that the existing baseline was consistent with requirements of the TWRS SEMP (LMHC 1998a), and provides an adequate foundation for continuing baseline development. The report recommendations concerning the requirements baseline will be considered in the DRD Rev. 1 and Advanced Conceptual Design products. Recommendations concerning SE management processes will be implemented through this SEMIP.

\subsubsection{SEMIP Application}

This SEMIP describes the entire technical baseline, concluding with Critical Decision 4 (Authorization to begin operations), at the end of the operational baseline (See TWRS SEMP Fig. 4). Existing baseline products which support the Project validation planned for April 1998 are summarized. However, the focus of the SEMIP is on the near-term products and processes necessary for completion of the design baseline and facility construction. The SEMIP provides a "road map" for systems engineering application for the project duration.

\subsubsection{Project Risks}

W-465 Project risks have been well defined and documented at both the project and program levels, and will be managed according to the process described in section 2.3.2 (Risk Management). The independent baseline assessment described in Section 1.2.1 (Parsons 1998a) concluded that there were no major risks associated with the Project technical baseline as of March 1998.

\subsubsection{SE Graded Approach}

The application of systems engineering to Project W-465 employs a graded approach, as outlined in HNF-IP-0842 Vol. IV, Sec. 1.2 (TWRS Systems Engineering Grading Guidelines, draft). Rather than grading the Project as a whole, the grading process has been applied to the major project systems, in accordance with the guidance of the revised TWRS SEMP (LMHC 1998a). The two major systems for the project are (1) Storage/disposal vaults and waste handling equipment, and (2) ILAW transport/packaging systems. A formal grading process was applied for each of the above systems, using a table of risk and complexity factors taken from HNF-IP$0842 \mathrm{Vol}$. IV, Sec 1.2, and is presented in Appendix A (Tables A.1 and A.2). The results of the 
grading process are used to determine the SE products and processes necessary to the subject systems, as outlined in the Grading Guidelines. The TWRS SEMP. was also referenced to determine necessary baseline products. Section 2 of this document addresses resulting management processes, and Section 3 addresses technical baseline products.

Vaults and Handling Equipment: The formal grading process presented in Table A.1 results in a Category SE-2 application, as described in the TWRS Systems Engineering Grading Guidelines. SE-2 systems require a selective application of systems engineering, with some SE activities performed informally. The risk and level of complexity for the vault systems are low within the context of the overall TWRS program. The vault storage and associated waste handling systems involve simple architecture elements subject to a complex set of environmental requirements. There is some risk in the RCRA permitting process, and Project interfaces with private contractors are complex and entail a degree of uncertainty at present. The greatest risk for the W-465 Project may be the time constraints. The SE processes required for the storage systems will include a disciplined design process with the associated design reviews; test and evaluation planning and documentation; operations infrastructure development (procedures, training, emergency preparedness); and a formal readiness review process. Management Systems for configuration control, formal interface control, and risk and decision management will also be required.

ILAW Transport and Packaging: The formal grading process presented in Table A.2 results in a Category SE-2 application, as described in the TWRS Systems Engineering Grading Guidelines. SE-2 systems require a selective application of systems engineering, with some SE activities performed informally. The basic architecture for the transportation system (truck with shielded cab, trailer, shipping container, and access road ways) is simple and similar to other transportation systems used at the Hanford Site. The relatively low source term and the high degree of confinement provided by the immobilized waste matrix and the ILAW packages should dictate a set of transportation requirements less stringent than those commonly employed for other on-site shipments. The risk involved in designing and procuring or constructing a system that will meet the transportation safety program requirements is minimal. The SE processes and products required for the transportation system focus on development of a Packaging Design Criteria document, the Safety Analysis Report for Packaging (SARP), procurement and/or construction specifications, and fabrication, construction, and acceptance under a Quality Assurance (QA) program. Development testing, preliminary design deliverables, and extensive design reviews and post-delivery testing and evaluation may not be necessary.

\subsubsection{Interface with Other Planning Documents}

TWRS top-level document relationships are shown in Figure 1 and Figure 2 of the TWRS SEMP (LMHC 1998a). This SEMIP implements the TWRS Plans and Procedures (DOE Good Practice Guides, TWRS Risk Management Plan, TWRS Configuration Management Plan) referenced in section 2 of the TWRS SEMP. The SEMIP also interfaces with the TWRS Program Baseline, which includes the TWRS Program Multi-Year Work Plan (project technical scope and schedule), the TWRS Program Plan (FDH 1998e), and TWRS Level 1 Logic. The Level 1 Logic provides an operational event sequence for the storage and disposal projects, and details 
HNF-2578, Rev, 0

interfaces with private contractor operations and other TWRS projects. At the Project level, the SEMIP interfaces with the upper-tier project plan for TWRS Projects W-465 and W-520, titled TWRS Retrieval and Disposal Mission Immobilized Low-Activity Waste Disposal Plan (NHC 1997b). A W-465 Project Management Plan will be developed following conceptual design, which will identify plans, organizational interfaces, management control systems, and reporting requirements for project managers. 


\subsection{SYSTEMS ENGINEERING MANAGEMENT PROCESSES}

This section describes the processes that are used to control the elements of the Integrated Baseline. Emphasis is placed primarily on control processes for the Technical Baseline.

\subsection{Risk Management}

The primary tool for communicating risk information is the TWRS Retrieval and Disposal Project Risk Management List (RML)(LMHC 1998h). The RML identifies Project risks; describes their likelihood and consequences; and identifies any residual risks, handling actions, and handling action status for Projects W-464, W-465, and W-520. The Storage and Disposal RML is currently being reviewed and updated on a monthly basis. The Tank Waste Remediation System Risk Management Plan (FDH 1998a), requires that Risk Management Implementation Plans be developed for each TWRS Project. The Risk Management Implementation Plan for Projects W-464 and W-465 is documented in the Storage and Disposal Project Risk Management Plan (WHC 1995b). Detailed guidance for performing risk management activities is provided in HNF-IP-0842, Volume IV, Section 2.6, "Risk Management" (LMHC 1997b), and further information is in the Tank Waste Remediation System Program Plan, Section 9.5 (FDH 1998e).

\subsection{Decision Management}

The Project will develop a Decision Document following conceptual design, which will be crossreferenced to the TWRS Level 1 logic and will outline decisions throughout the baseline development. The Decision Document will incorporate CDR uncertainties, DRD hold points, and define design agent risk management responsibilities. A formal decision process will be employed by the Project for decisions of major importance. A simplified process will be employed for decisions of lesser magnitude. The decision maker or responsible manager will determine to what extent the full decision process is required for each particular decision. Decision management for the project will be accomplished according to HNF-IP-0842, Volume IV, Section 2.7, "Decision Management" (LMHC 1997b). The Project emphasis will be on early identification of decision points and issues; effective communication to involved parties; elevation, if required, to the appropriate decision maker with any requested information and recommendations; timely decision making; and prompt communication of results.

\subsection{Interface Management}

Interface management will be essential for interfaces with $\mathrm{DOE}$, permitting authorities (Washington State Department of Ecology, Environmental Protection Agency), and PCs. ICDs and contract modifications are in development at the time of this writing. Interface management will be conducted in accordance with Identification and Control of TWRS Interfaces (LMHC 1998d); the TWRS SEMP, Section 2.3.2; and HNF-IP-0842 Vol. IV, Sec. 2.8, Interface Control. Further information on interface management is given in the Tank Waste Remediation System 
Program Plan (FDH 1998e) Section 9.7, and the Immobilized Low-Activity Waste Disposal Plan (NHC 1997b) Section 4.3, contains information on interfacing organizations and approval authorities. Interface Analysis and ICDs are addressed in Section 3 of this document.

\subsection{Configuration Management}

The configuration management requirements for TWRS are provided in the Tank Waste Remediation System Configuration Management Plan (FDH 1998d). The Tank Waste Remediation System Configuration Management Implementation Plan (CMIP)(LHMC, 1997f) will be revised to implement the requirements of this plan. Configuration Management provides a structure for identifying and controlling critical physical systems and configuration information (documents, drawings, data, logic diagrams, etc.). The products of the W-465 Project will be evaluated based on configuration management scope criteria to identify those products that will be controlled as configuration items. The minimum requirements for the configuration management scope criteria are defined in Configuration Management Plan (FDH 1997a). Hanford Site Technical Database (HSTD) configuration management will be maintained according to the TWRS Technical Database Manager Definition Document (LMHC 1998j).

Document control for the project is accomplished in accordance with HNF-PRO-232, "Project and Task Document Management." The Lockheed Martin Services, Inc. (LMSI) implementation of these requirements is found in the Documentation and Records Management Manual (LMSI 1995). Documents for W- 465 are maintained by a dedicated document control representative in the Document Service Center, Room 1310 of the 2440 Stevens Building, Richland, Washington.

\subsection{Technical Reviews}

Reviews are conducted to assess the development of the Project Baseline and to verify conformance to the TWRS baseline, the project mission, and requirements sources [e.g., (Final Safety Analysis Report (FSAR), Performance Assessment (PA), Test and Evaluation (T\&E) Plan, Fire Hazards Analysis, etc.]. Project reviews will be conducted according to the TWRS SEMP, Section 2.3.6.2, and will be completed prior to Project Critical Decisions (See Fig. 3.1). The three remaining reviews include (1) System Functional Review, (2) Detailed Design Review, and (3) Operational Startup Review. Other reviews may be added at the discretion of TWRS or the Project Manager. Management responsibilities for the reviews are presented in Table 2.1. Review products will be developed according to the guidance of DOE Order 430.1. Following is a definition of planned baseline products associated with the three Critical Decision Reviews:

System Functional Review (CD-2): The review product consists of a Review Comment Record (RCR) and a Project Validation Package submitted to DOE with a request for validation. This review is in progress for Projects W-464 and W-465 as of April, 1998.

Detailed Design Review (CD-3): The review product consists of an approved design released for construction. 


\section{HNF-2578, Rev. 0}

Operational Startup Review (CD-4): The review product consists of a summary letter from the Project to $\mathrm{DOE}$, declaring readiness for operations. 
HNF-2578, Rev. 0

\subsection{SE Management Process Responsibilities}

Table 2.1 provides a responsibility matrix between organizations/positions defined in the Immobilized Low-Activity Waste Disposal Plan (NHC 1997b) and the management processes identified in sections 2.1 through 2.5 above. The responsible organizations/positions listed are those internal to PHMC.

Table 2.1. Management Processes Responsibilities Matrix

\begin{tabular}{|c|c|c|c|c|c|c|c|}
\hline \multirow[b]{2}{*}{$\begin{array}{l}\text { Organization/ } \\
\text { Position }\end{array}$} & \multicolumn{4}{|c|}{ Management Process } & \multicolumn{3}{|c|}{ Technical Reviews } \\
\hline & $\begin{array}{c}\text { Risk } \\
\text { Mngmt. }\end{array}$ & $\begin{array}{l}\text { Decision } \\
\text { Mngmt. }\end{array}$ & $\begin{array}{l}\text { Config. } \\
\text { Mngmt. }\end{array}$ & $\begin{array}{l}\text { Interface } \\
\text { Mngmt. }\end{array}$ & $\begin{array}{c}\text { System } \\
\text { Functional } \\
\text { Review } \\
\text { (CD-2) }\end{array}$ & $\begin{array}{l}\text { Detailed } \\
\text { Design } \\
\text { Review } \\
\text { (CD-3) }\end{array}$ & $\begin{array}{l}\text { Operational } \\
\text { Startup } \\
\text { Review } \\
\text { (CD-4) }\end{array}$ \\
\hline Prog. Manager & $\mathrm{A} / \mathrm{L}$ & $\mathbf{A} / \mathbf{L}$ & $\mathbf{A}$ & $\mathbf{A}$ & $\mathbf{A}$ & $\mathbf{A}$ & $\mathbf{A}$ \\
\hline Proj. Manager & $\mathbf{A}$ & $\mathbf{A}$ & $\mathrm{A} / \mathrm{S}$ & $\mathbf{A}$ & $\mathbf{A}$ & $\mathbf{A} / \mathbf{L}$ & $\mathbf{A}$ \\
\hline EQS & $\mathbf{s}$ & $\mathbf{s}$ & $\mathrm{A} / \mathrm{S}$ & s & $\mathrm{A} / \mathrm{S}$ & $\mathbf{s}$ & $\mathbf{A} / \mathbf{S}$ \\
\hline Systems Eng. & $\mathbf{s}$ & s & $\mathbf{A} / \mathbf{L}$ & $\mathbf{L}$ & $\mathbf{s}$ & $\mathbf{s}$ & $\mathrm{s}$ \\
\hline Operations Rep. & S/R/C & A & $\mathbf{A}$ & $\mathrm{A} / \mathrm{S}$ & $\mathbf{A} / \mathbf{S}$ & $\mathbf{A} / \mathbf{S}$ & $\mathbf{A} / \mathbf{L}$ \\
\hline $\begin{array}{l}\text { TE\&NS and } \\
\text { Project Engr. }\end{array}$ & $\mathbf{S} / \mathbf{R} / \mathbf{C}$ & $\mathbf{S}$ & $\mathbf{A} / \mathbf{S}$ & $\mathrm{A} / \mathrm{S}$ & $\mathbf{A} / \mathbf{S}$ & $\mathbf{A} / \mathbf{S}$ & $\mathrm{A} / \mathrm{S}$ \\
\hline Design Agent & $s$ & $\mathrm{~s}$ & $\mathrm{C} / \mathrm{S}$ & $\mathbf{S}$ & $\mathbf{s}$ & $\mathbf{A} / \mathbf{S}$ & $\mathbf{s}$ \\
\hline Bus. Manager & $\mathbf{S} / \mathbf{R}$ & $\mathrm{s} / \mathrm{C}$ & & S & $s$ & $s$ & $\mathbf{s}$ \\
\hline $\begin{array}{l}\text { HNF-IP-0842 } \\
\text { Vol. IV Sec. \# }\end{array}$ & 2.6 & 2.7 & HNF-1900 & 2.8 & $\begin{array}{c}\text { GPG-FM- } \\
015\end{array}$ & $\begin{array}{c}\text { GPG-FM- } \\
015\end{array}$ & 3.12 \\
\hline
\end{tabular}

\section{Legend:}

A: Approve - Responsibility for process management and authority to issue documents.

C: $\quad$ Concurrence - Approval is requested but not mandatory.

L: $\quad$ Lead - Responsible for process performance or product preparation.

$\mathrm{R}$ : Review - Comments requested within position's or organization's area of expertise.

S: $\quad$ Support - Provide support for process performance or product preparation.

EQS: Environmental, Quality, and Safety

TE\&NS: TWRS Engineering and Nuclear Safety 
HNF-2578, Rev. 0

\subsection{SYSTEMS ENGINEERING PROCESS}

This section provides details of how systems engineering will be applied to the TWRS Project W-465 Technical Baseline development. A description of existing baseline products is given, as well as an outline of the SE processes and products to be used to further define the baseline during the design and construction phases of the project. Roles and responsibilities for major baseline product development are outlined in section 3.4.

\subsection{SYSTEMS ENGINEERING APPLICATION TO PROJECT W-465}

This subsection provides a narrative of SE products and processes applied to the project. The text explains the products, processes, and decision points which are shown graphically in Fig. 3.1 (W-465 Project Baseline Development Flow Diagram). Reference to the TWRS SEMP (LMHC 1998a) is made where applicable to avoid redundancy.

\subsubsection{Requirements Traceability}

The upper level functions that the TWRS Storage and Disposal program is required to provide are currently dictated by the TWRS Mission Analysis Report (MAR) (LMHC 1998b) and HSTD. A planned revision to the TWRS Operations and Utilization Plan (OUP) (LMHC 1997d) will incorporate private contractor data when it is released. Lower level functions and performance requirements for the project are defined in a DRD, Rev. 0 (SESC 1997), and Rev. 1 (SESC 1998a), and will be updated as necessary throughout design baseline development.

Requirements traceability will be maintained by documenting requirements in the HSTD through periodic change requests. Design criteria for the ILAW transport and packaging systems will be similarly input to the HSTD. This process is described in the TWRS SEMP (LMHC 1998a), section 2.3.5.

\subsubsection{Mission Analysis}

The TWRS SEMP (LMHC 1998a) does not require a MAR for projects which are defined by a top-down process, utilizing the missions defined in the TWRS MAR (LMHC 1998b). The mission and upper level functions for the Storage and Disposal program are well defined in the TWRS MAR (LMHC 1998b).

\subsubsection{Functions and Requirements/Specification Development}

The major functions that the TWRS program must perform to accomplish the storage and disposal missions are identified in the HSTD. Upper level performance requirements for throughput, storage capacity, storage durations, etc. for ILAW Storage are described in the TWRS MAR (LMHC 1998b) and the TWRS OUP (LMHC 1997d). The ILAW storage 
functions and requirements decomposition is provided in the DRD (SESC 1998a). The DRD will provide the basis for Level 1 specifications, which will be generated from the HSTD following conceptual design. Functions and requirements for the ILAW transport and packaging systems will be captured in a design criteria document or equivalent, and input to the HSTD.

\subsubsection{Alternative Analysis and Selection}

Alternative storage facility architectures to be evaluated for Project W-465 were defined in the letter from R. E. Murkowski, WHC, to P. E. Lamont, WHC, Immobilized Low-Level Waste Interim Storage Alternatives, (WHC 1996c). The letter defines four ILAW storage facility options, compares access options to the existing grout vaults (roof and wall entry), and defines three waste transport options. This alternative description letter was followed by a decision plan which defines the ILLW interim storage architecture decision responsibilities, strategy, criteria, required information, and schedule, in a letter from D. L. Washenfelder to R. J. Murkowski, Immobilized Low-Level Waste Interim Storage Architecture Selection Decision Plan (WHC 1996d). The formal architecture evaluation for the ILAW Storage function is documented in the AGA (WHC 1996a). The privatization contracts (DOE-RL 1996a,b) limit ILAW transportation options to over-road transport by truck, thereby eliminating the need for a formal alternative evaluation. The DOE documented concurrence with the AGA recommendations for ILAW storage in a letter from W. J. Taylor, DOE-RL, to President, WHC, Milestone Completion - Issue Low-Level Waste Interim Storage Engineering Evaluation (DOE 1996a).

The W-465 Advanced Conceptual Design process will analyze alternatives for high-risk elements identified in the Conceptual Design Report (FDNW 1997a) and the TWRS Storage and Disposal Risk Management List. Alternative analysis will continue throughout design development until all lower-level architecture is defined.

\subsubsection{Interface Analysis}

An initial project interface analysis is provided in Identification and Control of TWRS Interfaces (LMHC 1998d). Section 3.1.6 of this document augments that analysis. Guidance on interface analysis is given in the TWRS SEMP (LMHC 1998a) and WHC-IP-0842 Vol. IV, Sec. 2.8 (Interface Control). Further interface analysis will be addressed in updated TWRS Level 1 logics and supporting documentation, which will be reflected in annual updates to the TWRS MultiYear Work Plan (MYWP).

\subsubsection{Interface Control Documentation}

The W-465 Project has a number of interfaces with other LMHC organizations, other PHMC contractors, and the private contractors responsible for delivering the ILAW product. There are also several external interfaces with the Department of Energy and regulatory agencies. Physical interfaces will be documented in ICDs, and administrative interfaces will be managed through contract modifications or memorandums of agreement. A description of each of the currently 
HNF-2578, Rev. 0

identified internal and external interfaces is provided in following sections.

3.1.6.1 Privatization Contractor Interfaces. These interfaces are currently documented in the ICD-15 (FDH 1997b), between DOE and the PCs. A counterpart interface document will be prepared by the W-465 Project for the privatization interface.

3.1.6.2 Infrastructure Interfaces. Infrastructure interfaces between LHMC and other Hanford contractors include utilities, roadways, secondary waste disposal, and analytical laboratory services. A summary of Hanford contractor services is given in the Tank Waste Remediation System Retrieval and Disposal Mission Technical Baseline Summary Description, HNF-1901 (FDH 1998b). Contracts between Flour-Daniel Hanford and supporting contractors[ DE\&S Hanford, Inc. (DESH), DynCorp Tri-Cities Services, Inc. (DYN), and Waste Management Federal Services of Hanford, Inc. (WMFSH)) will be modified as required, based on requirements provided by the TWRS Project and documented in the HSTD. Interface documentation will also be developed for infrastructure elements internal to TWRS including telecommunications and remote monitoring systems, as required. Staffing for facility operations and management responsibilities for project turnover and readiness preparations will be negotiated by the Operations Manager.

3.1.6.3 Environmental Interface. ILAW Storage Facility monitoring plans will be developed to address pre-operational, operational, and post-closure monitoring of the storage facility and surrounding environment. Project interface may be required with Hanford Site monitoring programs, DOE-RL, and PCs to perform these functions.

3.1.6.4 Secondary Waste Interfaces. Interfaces for handling of secondary wastes including solid wastes and vault leachate will be developed as necessary. Interfaces with site facilities such as the Liquid Effluent Retention Facility (LERF) or the Treated Effluent Disposal Facility (TEDF), regulators, DOE-RL, and other Hanford Site contractors may be required.

3.1.6.5 Interfaces with Other TWRS Projects. An interface will be developed with TWRS Project W-520 which will provide the required closure barrier design for the W-465 Facility. A future project will address facility closure.

\subsubsection{System Assessments/Evaluations}

The TWRS SEMP (LMHC 1998a) includes a requirement to determine the extent to which the existing vault systems are able to perform the Project mission. This requirement has been satisfied by the architecture assessments in the AGA Report (WHC 1996a) and the W-465 CDR (FDNW 1997a). Further assessment will be conducted during construction. 


\subsubsection{Specialty Engineering Analysis and Integration}

In addition to design engineering and project and construction management, specialty engineering disciplines as listed in the TWRS SEMP (LMHC 1998a) will be used in Project baseline development. Specialty engineering analyses will be documented and traceable. Results will be used during functional and performance analysis and as input into the appropriate systems, structures, and components (SSC) specifications. The following are specialty engineering applications which have been or will be required for Project W-465:

3.1.8.1 Human Systems Integration: Human systems integration is used to reduce the potential for human error in system operation and ensure system safety, operational efficiency, ease of maintainability, and reliability. The CDR (FDNW 1997a) outlines requirements for the work environment at the vault facility (e.g. ventilation and continuous air monitors). Further input to the baseline will be derived from the Operations and Maintenance (O\&M) Concept, Reliability Availability, and Maintenance (RAM) analysis, and O\&M input during preliminary and detailed design.

3.1.8.2 Reliability, Availability, and Maintainability: The O\&M Concept will provide a basis for RAM analysis, which will be completed when design detail is sufficiently developed (typically during detailed design). The RAM analysis will be evaluated against design requirements when completed.

3.1.8.3 Safety: A Preliminary Safety Evaluation for Project W-465, Immobilized Low-Activity Waste Interim Storage (PSE) (NHC 1997a) has been completed for the project. Other safety analyses are planned, including a SARP for the ILAW packaging systems. These documents are used as sources for design requirements. Further safety analysis will be conducted according to the Master Safety Plan for Immobilized Low-Activity and High-Level Waste (Mouette 1998), which outlines the authorization basis development.

3.1.8.4 Quality: A Quality Assurance Program Plan (QAPP), based on the requirements of the Quality Assurance Program Description (FDH 1997d), will be written for the project during the conceptual phase, and will provide guidance for project activities through construction. The Project Test and Evaluation Plan will identify other test and evaluation quality elements. Project quality procedures will be developed and implemented to address the requirements of the Quality Assurance Program Description (FDH 1997d).

3.1.8.5 Regulatory Compliance: The Permitting Plan for the Immobilized Low-Activity Waste Project (LMHC 1997c) provides the current project strategy and identifies analyses and document submittals required by regulation. Revisions of the Permitting Plan will be written as required. Approved permits and other regulatory decisions become project constraints and will be used as requirements source documents during design baseline development.

3.1.8.6 Facility Startup: Following completion of W-465 Facility construction and testing, and prior to ILAW storage operations, the project will complete operations readiness preparations to include operation and maintenance procedure validation and training, emergency preparedness, 
issuing as-built piping and instrument diagrams (P\&IDs) and essential drawings, spare parts procurement for initial operations, and operational staffing plans.

3.1.8.7 ILAW Performance Assessment: If ILAW disposal (vs. storage) is determined to be the mission for Project W-465, the Project will integrate design requirements from the Hanford Low-Activity Tank Waste Performance Assessment (Mann et al.1998) and subsequent revisions. (See Fig. 3.1) The Performance Assessment (PA) evaluates the long-term potential for contaminant migration from disposal systems to estimate its potential effect on human health and the environment. The function of the PA is to provide "reasonable assurance" that the disposal activity will perform as expected in the design and meet long-term performance objectives. Further details are given in the Immobilized Low-Activity Waste Disposal Plan (NHC 1997b). Major products supporting a revised Performance Assessment (scheduled for 2001) include waste form data packages and geotechnical data packages. An ILAW disposal authorization will require approval of both the PA and the Site Composite Analysis. The Site Composite Analysis evaluates impacts of previous and current disposal actions from other sources, with an emphasis on groundwater contamination.

\subsubsection{Operations and Maintenance Concept Development}

An O\&M Concept for the W-465 project will be developed from architecture and design concepts that address package acceptance, emplacement, monitoring operations, and preventive or corrective maintenance. Throughput and other processing requirements affecting operational capabilities and operating constraints are also part of the O\&M Concept. The time/motion study provided in the CDR Appendix K (FDNW 1997a) will be used as a basis for O\&M Concept development, to be completed following Preliminary Design. The O\&M Concept will be written to the level of information available at the time, and will be updated as the project design matures. The TWRS SEMP Section 3.2.2 provides further information.

\subsubsection{Design Optimization}

A trade study has been completed to evaluate the fraction of ILAW waste which will be contact handled, versus remote handled, titled Phase 1 Immobilized Low-Activity Waste Operational Source Term Report (SESC 1998b). These studies will be identified in the MYWP and will support the design baseline. Other studies will be completed as necessary to resolve conceptual design uncertainties or other design issues. Design optimization guidance is given in the TWRS SEMP (LMHC 1998a).

\subsubsection{Physical System Test and Evaluation}

The Project will develop a T\&E Plan following preliminary design to verify that end products perform their design functions and meet all established requirements prior to project turnover. A graded approach will be used to determine the degree to which elements of T\&E are applied to W-465 systems. Required test procedures will be developed in the design baseline, and 
subsequent test reports will be documented in the operational baseline. The ILAW packaging and transportation systems will be verified in accordance with the vendor testing and QA/Quality Control (QC) requirements identified in the fabrication/procurement specifications. Additional post-receipt inspections and testing, if any, will be identified in the procurement specifications.

The T\&E Plan for the grout vault systems and the procurement specifications, and all test and QA/QC procedures used for the project will be maintained current and revised by a formal process if performance requirements or the associated test method or acceptance criteria are to be changed. The complete set of T\&E results will be reviewed as part of the turnover process, and identified issues will be formally resolved prior to the declaration of operational readiness. Development and execution of T\&E will be in accordance with HNF-2029, Tank Waste Remediation System Test and Evaluation Plan (LMHC 1998i) and the appropriate sections of the TWRS Administrative Manual, HNF-IP-0842.

\subsubsection{Integrated Logistics Support}

The TWRS SEMP requirements for logistics support planning will be met by baseline documents including the O\&M Concept, O\&M Procedures, Packaging and Transport Design Criteria, Design Reports, RAM Analysis, and Training Needs Analysis. The Project architecture is relatively simple and does not warrant development of stand-alone logistics support plans.

\subsubsection{Project Validation}

The basis for project validation is the technical information, cost estimates, and schedule developed during conceptual design. Project W-465 validation is described in the Immobilized Low-Activity Waste Disposal Plan (NHC 1997b). A Project validation review is scheduled for April 1998, with yearly updates planned.

\subsubsection{Decision Points}

Critical Decision 1, authorization to initiate conceptual design, has been completed for the project. Remaining critical decisions are shown in Fig. 3.1, and are described in the Immobilized Low-Activity Waste Disposal Plan (NHC 1997b). Completed decisions include issuance of the TWRS Environmental Impact Statement Record of Decision (Federal Register 1997), which confirmed interim storage of ILAW at the Hanford Site and final disposal of ILAW in nearsurface disposal facilities on Site. Additionally, the Nuclear Regulatory Commission (NRC) granted an incidental waste determination for the low-activity waste, subject to certain conditions, in June 1997 (NRC 1997). 


\subsection{TECHNICAL BASELINE DEVELOPMENT}

Technical baseline development is described in detail in GPG-FM-10 (Project Execution and Engineering Management Planning). Baseline development is an iterative process in which several cycles of functions and requirements definition, alternatives analysis, and system design are necessary. This iterative process ensures that the project end products satisfy the mission needs. This iterative process is currently reflected in the W- 465 baseline by revisions to the DRD (SESC 1997, SESC 1998a) and plans for advanced conceptual design, which will build on the existing CDR (FDNW 1997a).

Figures 3.1a, 3.1b, and 3.1c illustrate the chronological development of the Project baseline. Supporting processes and documents including safety analysis, project reviews, and test and evaluation functions are shown as they relate to baseline development. The timing of some elements (e.g., Review of PC deliverables) may vary depending upon actual delivery dates. 
Figure 3.1a PROJECT W-465 BASELINE

DEVELOPMENT FLOW DIAGRAM
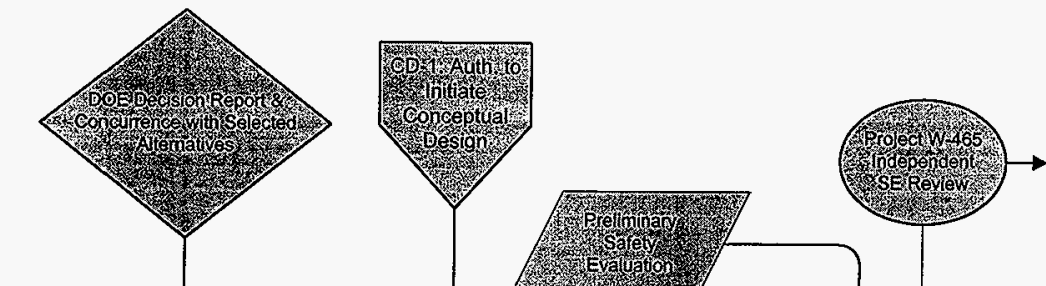
Consider
Recommendations in
DRD Rev. 1 and
Advanced CDR
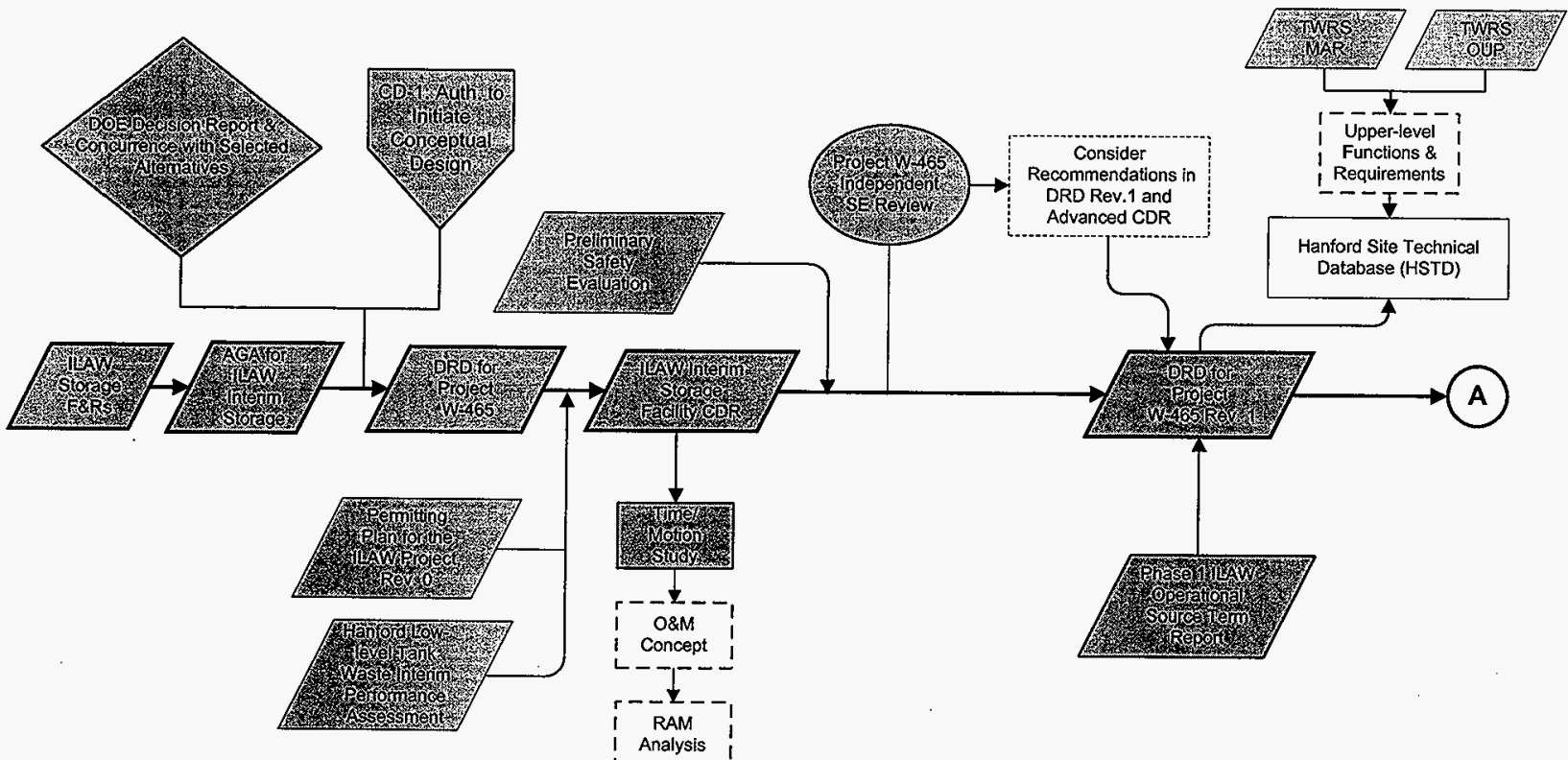

ACRONYM LIST

AGA Alternative Generation and Analysis

CDR Conceptual Design Report

DRD Design Requirements Document

F\&R Functions and Requirements

ILAW Immobilized Low-Activity Waste

JMN Justification of Mission Need

MAR Mission Analysis Report

O\&M Operations and Maintenance

PSE Preliminary Safety Evaluation

RAM Reliability, Availability, and Maintainability

SE Systems Engineering

TWRS Tank Waste Remediation System

\% as of April 1998 
Figure 3.1b PROJECT W-465 BASELINE

DEVELOPMENT FLOW DIAGRAM

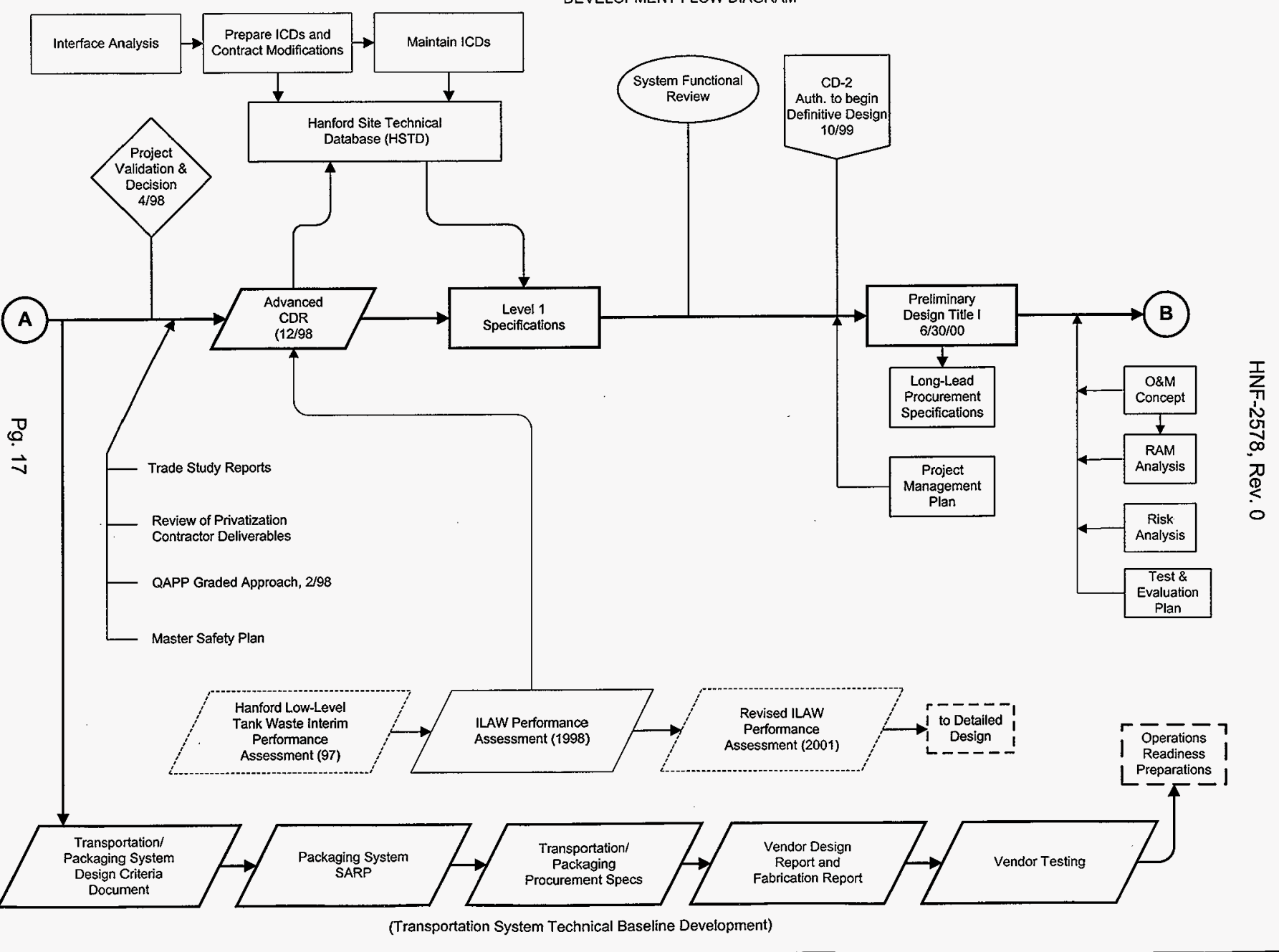


HNF-2578, Rev. 0

\subsection{MAJOR TECHNICAL BASELINE PRODUCTS}

Table 3.1 identifies and describes major products that comprise the W-465 Technical Baseline. Required products were determined according to the graded approach described in Section 1, and were derived from the TWRS SEMP (LMHC 1998a) and the TWRS Systems Engineering Grading Guidelines (HNF-IP-0842, Vol. IV, Sec 1.2, Draft). Descriptions of project deliverables were derived in part from Subcontract Number 80232764-9-K001, Defense Nuclear Facilities Safety Board Recommendation 92-4 Implementation Plan, Revision 2N, Commitment 5.2.2(d) (LMHC, 1997e) and the Immobilized Low-Activity Waste Disposal Plan (NHC 1997b).

Table 3.1. SE Processes/Products Required for Baseline Development

\begin{tabular}{|c|c|c|}
\hline $\begin{array}{c}\text { TWRS SEMP } \\
\text { Process Requirement }\end{array}$ & W-465 Deliverable & Description \\
\hline $\begin{array}{l}\text { Functions and } \\
\text { Requirements }\end{array}$ & $\begin{array}{l}\text { 1. Functional Requirements - ILLW } \\
\text { Interim Storage Alternatives (WHC } \\
\text { 1995a) } \\
\text { 2. DRD Rev. O (SESC 1997). } \\
\text { 3. DRD Rev. 1. (SESC 1998a). } \\
\text { 4. HSTD Revision: W-465 F\&Rs to } \\
\text { be incorporated into HSTD, based on } \\
\text { DRD. }\end{array}$ & $\begin{array}{l}\text { Defines level } 5 \text { and } 6 \text { functions and } \\
\text { requirements for W- } 465 \text {. } \\
\text { See TWRS SEMP, Table } 2 \text { (Level } 1 \text { and } 2 \\
\text { Specifications). } \\
\text { Will incorporate updated project functions } \\
\text { and performance requirements. } \\
\text { HSTD will be updated periodically } \\
\text { throughout project evolution, and will } \\
\text { provide requirements traceability. }\end{array}$ \\
\hline Alternative Analysis & $\begin{array}{l}\text { 1. AGA for ILAW Interim Storage } \\
\text { (Rev. 0)(WHC 1996a). }\end{array}$ & See TWRS SEMP, Table 2. \\
\hline $\begin{array}{l}\text { O\&M Concept } \\
\text { and RAM Analysis }\end{array}$ & $\begin{array}{l}\text { 1. Time/Motion Study (CDR App. K) } \\
\text { (FDNW 1997a). } \\
\text { 1. O\&M Concept } \\
\text { (See Note 1.) } \\
\text { 2. RAM Analysis } \\
\text { (See Note 1.) }\end{array}$ & $\begin{array}{l}\text { Basis for O\&M concept. } \\
\text { See TWRS SEMP, Table } 2 \text {. } \\
\text { Reliability, Availability, Maintainability } \\
\text { Analysis of W-465 SSCs, based on O\&M } \\
\text { Concept. }\end{array}$ \\
\hline
\end{tabular}


HNF-2578, Rev. 0

\begin{tabular}{|c|c|c|}
\hline $\begin{array}{c}\text { TWRS SEMP } \\
\text { Process Requirement }\end{array}$ & W-465 Deliverable & Description \\
\hline Decision Documents & $\begin{array}{l}\text { 1. Record of Decision for the TWRS } \\
\text { System (Federal Register, 1997). } \\
\text { 2. NRC Incidental Waste } \\
\text { Determination (NRC 1997). } \\
\text { 3. DOE Decision Report and } \\
\text { Concurrence (DOE 1996a). } \\
\text { 4. Critical Decision 1: letter, A. L. } \\
\text { Alm to DOE-RL (DOE-RL, 1996c). } \\
\text { 5. Tank Waste Retrieval RTP } \\
\text { Independent Review (Lerch, 1997). } \\
\text { 6. Project Validation Package and } \\
\text { Decision (See Note 1.) } \\
\text { 7. Project Decision Document } \\
\text { (See Note 1.) } \\
\text { 8. Critical Decision 2. (See Note 1.) } \\
\text { 9. Critical Decision 3. (See Note 1.) } \\
\text { 10. Critical Decision 4. (See Note 1.) }\end{array}$ & $\begin{array}{l}\text { Confirms ILAW storage at Hanford Site and } \\
\text { final disposal of ILAW on site. } \\
\text { Allows ILAW disposal in shallow land } \\
\text { disposal facilities, such as grout vaults. } \\
\text { DOE concurrence with AGA } \\
\text { recommendations. Also documents } \\
\text { milestone completion for "Issue Low-Level } \\
\text { Waste Interim Storage Engineering } \\
\text { Evaluation." } \\
\text { Provides DOE-HQ authorization to initiate } \\
\text { conceptual design. } \\
\text { Documents status of TWRS program plans } \\
\text { and capabilities to support Privatization } \\
\text { Phase 1B. and Readiness To Proceed. } \\
\text { Basis for budget request. } \\
\text { See Section } 2.2 \text { of this document. } \\
\text { Authorization to begin definitive design. } \\
\text { Authorization to begin construction. } \\
\text { Authorization to begin operations. }\end{array}$ \\
\hline $\begin{array}{l}\text { ICDs and } \\
\text { Memorandums } \\
\text { of Agreement }\end{array}$ & $\begin{array}{l}\text { 1. ICDs are summarized in } \\
\text { Identification and Control of TWRS } \\
\text { Interfaces (LMHC 1998d). } \\
\text { (See Note 1.) } \\
\text { 2. Contract Modifications. } \\
\text { (See Note 1.) }\end{array}$ & $\begin{array}{l}\text { See TWRS SEMP, Table } 2 . \\
\text { Document administrative interfaces between } \\
\text { site contractors. }\end{array}$ \\
\hline
\end{tabular}


HNF-2578, Rev. 0

\begin{tabular}{|c|c|c|}
\hline $\begin{array}{c}\text { TWRS SEMP } \\
\text { Process Requirement }\end{array}$ & W-465 Deliverable & Description \\
\hline $\begin{array}{l}\text { Specialty Engineering } \\
\text { Analysis: } \\
\text { Safety and QA/QC }\end{array}$ & $\begin{array}{l}\text { 1. QAPP. (See Note 1.) } \\
\text { 2. Preliminary Safety Evaluation } \\
\text { (NHC, 1997a). } \\
\text { 3. SARP for ILAW packaging system. } \\
\text { (See Note 1.) } \\
\text { 4. PSAR. } \\
\text { (See Note 1.) } \\
\text { 5. Hanford Low-Level Immobilized } \\
\text { Waste Interim Performance } \\
\text { Assessment (Mann, et al. 1997). } \\
\text { 6. 1998 ILAW Performance } \\
\text { Assessment. (Mann et al. 1998) } \\
\text { 7. PA Waste Form Data Packages. } \\
\text { (See Note 1.) } \\
\text { 8. PA Geotechnical Data Packages. } \\
\text { (See Note 1.) } \\
\text { 9. 2001 ILAW Performance } \\
\text { Assessment. (See Note 1.) } \\
\text { 10. Site Composite Analysis. } \\
\text { (See Note 1.) } \\
\text { 11. Storage Facility FSAR or TWRS } \\
\text { Authorization Basis Amendment. } \\
\text { (See Note 1.) }\end{array}$ & $\begin{array}{l}\text { Identifies QA/QC requirements for project. } \\
\text { Initial safety analysis of transport and } \\
\text { storage system. } \\
\text { Safety analysis of ILAW packaging and } \\
\text { shipping container. } \\
\text { Provides analysis assumptions and required } \\
\text { preventive and mitigative design features for } \\
\text { input to Preliminary Design. } \\
\text { Establishes basis for performance } \\
\text { requirements for ILAW disposal. } \\
\text { Updated PA. } \\
\text { Data to support Final Performance } \\
\text { Assessment. } \\
\text { Data to support Final Performance } \\
\text { Assessment. } \\
\text { Final PA approval required for ILAW } \\
\text { disposal authorization. } \\
\text { Provides analysis of composite } \\
\text { environmental effects of Hanford facilities. } \\
\text { Approval required for ILAW disposal } \\
\text { authorization. } \\
\text { Final safety basis including accident analysis } \\
\text { and Technical Safety Requirements. } \\
\text { and mitigating features, and TSR } \\
\text { surveillance and action statement } \\
\text { requirements must be incorporated into final } \\
\text { design deliverables. }\end{array}$ \\
\hline
\end{tabular}


HNF-2578, Rev. 0

\begin{tabular}{|c|c|c|}
\hline $\begin{array}{c}\text { TWRS SEMP } \\
\text { Process Requirement }\end{array}$ & W-465 Deliverable & Description \\
\hline $\begin{array}{l}\text { Specialty Engineering } \\
\text { Analysis Reports: } \\
\text { Regulatory }\end{array}$ & $\begin{array}{l}\text { 1. Permitting Plan for ILAW Project } \\
\text { (LHMC 1997b). } \\
\text { 2. Revised Permitting Plan for ILAW } \\
\text { Disposal at Grout Vaults } \\
\text { (See Note 1.) } \\
\text { 3. RCRA Part A Permit Application. } \\
\text { (Existing for former grout facility) } \\
\text { 4. RCRA Part B Permit Application. } \\
\text { (See Note 1.) }\end{array}$ & $\begin{array}{l}\text { Environmental permitting requirements for } \\
\text { transport and interim storage during } \\
\text { Privatization Phase } 1 \text {. } \\
\text { Anticipated revision to incorporate } \\
\text { permitting for ILAW disposal at grout } \\
\text { vaults, based on DOE disposal decision. } \\
\text { Establishes regulatory commitments for } \\
\text { RCRA compliance. } \\
\text { Establishes final regulatory requirements for } \\
\text { RCRA compliance. }\end{array}$ \\
\hline Risk Management & $\begin{array}{l}\text { 1. Storage and Disposal Project Risk } \\
\text { Management Plan (WHC 1995b). } \\
\text { 2. Project Risk Management List } \\
\text { (LHMC 1998h). }\end{array}$ & $\begin{array}{l}\text { Establishes basis for project risk } \\
\text { management. } \\
\text { Project-specific risk tracking list, reviewed } \\
\text { monthly. }\end{array}$ \\
\hline $\begin{array}{l}\text { Specialty Engineering } \\
\text { Analysis: } \\
\text { Project Management }\end{array}$ & $\begin{array}{l}\text { 1. TWRS Retrieval and Disposal } \\
\text { Mission, ILAW Disposal Plan (NHC, } \\
\text { 1997b). } \\
\text { 2. Systems Engineering Management } \\
\text { and Implementation Plan } \\
\text { 3. Project Management Plan. } \\
\text { See Note 1. } \\
\text { 4. Project Validation Package. } \\
\text { See Note 1. }\end{array}$ & $\begin{array}{l}\text { Project Plan specific to ILAW storage and } \\
\text { disposal (Projects W-465 \& W-520). } \\
\text { Defines SE application to W-465, according } \\
\text { to TWRS SEMP guidance. } \\
\text { Identifies plans, interfaces, management } \\
\text { control systems, and reporting requirements } \\
\text { for W-465. } \\
\text { Provides basis for project budget request. }\end{array}$ \\
\hline Trade Studies & $\begin{array}{l}\text { 1. Phase } 1 \text { Immobilized Low-Activity } \\
\text { Waste Operational Source Term } \\
\text { Report (SESC 1998b). } \\
\text { 2. Engineering Studies } \\
\text { (See Note 1.) }\end{array}$ & $\begin{array}{l}\text { Provides estimate of number of contact vs. } \\
\text { remote handled ILAW packages. } \\
\text { Will address high-risk elements identified in } \\
\text { CDR and Risk Management List. }\end{array}$ \\
\hline
\end{tabular}


HNF-2578, Rev. 0

\begin{tabular}{|c|c|c|}
\hline $\begin{array}{c}\text { TWRS SEMP } \\
\text { Process Requirement }\end{array}$ & W-465 Deliverable & Description \\
\hline Design Criteria & $\begin{array}{l}\text { 1. W-465 DRD Rev. 0. (SESC 1997). } \\
\text { 2. W-465 DRD Rev. 1. (SESC } \\
\text { 1998a). } \\
\text { 3. Level } 1 \text { Specifications } \\
\text { (See Note 1.) } \\
\text { 4. Transportation/Packaging System } \\
\text { Specifications (See Note 1.) }\end{array}$ & $\begin{array}{l}\text { See TWRS SEMP, Table 2, (Level } 1 \& 2 \\
\text { Specifications). } \\
\text { Incorporates updated functions and } \\
\text { performance requirements. } \\
\text { See TWRS SEMP, Table } 2 . \\
\text { Will provide detailed functions and } \\
\text { requirements for transportation and } \\
\text { packaging system. }\end{array}$ \\
\hline $\begin{array}{l}\text { Project Conceptual } \\
\text { Design }\end{array}$ & $\begin{array}{l}\text { 1. ILAW Interim Storage Facility } \\
\text { Project W-465 Conceptual Design } \\
\text { Report, HNF-1975 (FDNW 1997). } \\
\text { 2. Advanced Conceptual Design } \\
\text { Studies (See Note 1.) }\end{array}$ & $\begin{array}{l}\text { Provides conceptual design and estimated } \\
\text { cost of grout vault modification. } \\
\text { Will complete conceptual design according } \\
\text { to revised DRD. }\end{array}$ \\
\hline $\begin{array}{l}\text { Requirements Baseline } \\
\text { Review }\end{array}$ & $\begin{array}{l}\text { System Functional Review. } \\
\text { (See Note 1.) }\end{array}$ & $\begin{array}{l}\text { First of three remaining project reviews } \\
\text { required by TWRS SEMP (LMHC 1998a). } \\
\text { Review is required following completion of } \\
\text { conceptual design. }\end{array}$ \\
\hline $\begin{array}{l}\text { Preliminary and } \\
\text { Detailed Design }\end{array}$ & $\begin{array}{l}\text { 1. Preliminary Design (Title 1) } \\
\text { (See Note 1.) } \\
\text { 2. Detailed Design (Title II) } \\
\text { (See Note I.) } \\
\text { 3. Transportation System Design } \\
\text { (See Note 1.) } \\
\text { 4. Master Equipment List } \\
\text { (See Note 1.) } \\
\text { 5. Fabrication and Construction } \\
\text { Drawings (See Note 1.) } \\
\text { 6. Construction and Procurement } \\
\text { Specifications (See Note 1.) } \\
\text { 7. Design Analysis Reports } \\
\text { (See Note 1.) }\end{array}$ & $\begin{array}{l}\text { Preliminary and detailed designs advance the } \\
\text { conceptual design with input from specialty } \\
\text { engineering, trade studies, etc. Completion } \\
\text { of detailed design will satisfy all project } \\
\text { performance requirements. } \\
\text { A stand-alone document for vehicle and } \\
\text { shipping container design may not be } \\
\text { necessary; fabrication and procurement } \\
\text { specs may be developed directly from design } \\
\text { criteria documents and SARP. } \\
\text { See TWRS SEMP, Table } 2 \text {. } \\
\text { See TWRS SEMP, Table } 2 \text { (Design } \\
\text { Drawings). } \\
\text { See TWRS SEMP, Table } 2 \text {. } \\
\text { See TWRS SEMP, Table } 2 \text {. }\end{array}$ \\
\hline
\end{tabular}


HNF-2578, Rev. 0

\begin{tabular}{|c|c|c|}
\hline $\begin{array}{c}\text { TWRS SEMP } \\
\text { Process Requirement }\end{array}$ & W-465 Deliverable & Description \\
\hline Test and Evaluation & $\begin{array}{l}\text { 1. Project T\&E Plan } \\
\text { (See Note 1.) } \\
\\
\text { 2. Test Procedures. } \\
\text { (See Note 1.) } \\
\text { 3. Test Reports. } \\
\text { (See Note 1.) }\end{array}$ & $\begin{array}{l}\text { Document the specific SSC test and } \\
\text { evaluation methods, procedures used to } \\
\text { verify SSC performance at various stages of } \\
\text { baseline development. Also implements } \\
\text { elements of QA/QC plan. } \\
\text { See TWRS SEMP, Table } 2 \text {. } \\
\text { See TWRS SEMP, Table } 2 \text {. }\end{array}$ \\
\hline $\begin{array}{l}\text { Design Baseline } \\
\text { Review }\end{array}$ & $\begin{array}{l}\text { Detailed Design Review. } \\
\text { (See Note 1.) }\end{array}$ & $\begin{array}{l}\text { Second of three remaining project reviews } \\
\text { required by TWRS SEMP. }\end{array}$ \\
\hline $\begin{array}{l}\text { As-Built Drawings and } \\
\text { Equipment Labeling }\end{array}$ & $\begin{array}{l}\text { P\&IDs (One-line diagrams), and } \\
\text { essential drawings as defined by } \\
\text { Cognizant Engineer. (See Note 1) }\end{array}$ & See TWRS SEMP, Table 2. \\
\hline O\&M Procedures & O\&M Procedures (See Note 1.) & $\begin{array}{l}\text { See TWRS SEMP, Table } 2 \text { (Operations } \\
\text { Manuals/ Procedures, Maintenance Manuals/ } \\
\text { Procedures) }\end{array}$ \\
\hline Safety Equipment List & $\begin{array}{l}\text { Safety Equipment List (Part of } \\
\text { Detailed Design.) (See Note 1.) }\end{array}$ & See TWRS SEMP, Table 2. \\
\hline $\begin{array}{l}\text { Operations, } \\
\text { Maintenance, } \\
\text { Engineering and } \\
\text { Support Staff Training }\end{array}$ & $\begin{array}{l}\text { 1. Job Task Analysis (JTA), } \\
\text { classroom and on-the-job (OJT) for } \\
\text { certified operators. (See Note 1.) } \\
\text { 2. Training Needs Analysis } \\
\text { (See Note 1.) }\end{array}$ & $\begin{array}{l}\text { Documents that operators, craftsmen, and } \\
\text { technicians have been trained to a required } \\
\text { proficiency level for system operation and } \\
\text { maintenance. Also includes training and } \\
\text { certifications as required for management, } \\
\text { engineers, and other staff. }\end{array}$ \\
\hline Licenses and Permits & $\begin{array}{l}\text { Required RCRA, Construction, and } \\
\text { other permits and licenses. } \\
\text { (See Note 1.) }\end{array}$ & See TWRS SEMP, Table 2. \\
\hline Operational Readiness & $\begin{array}{l}\text { Operational Readiness Review and/or } \\
\text { Readiness Assessment by Contractor } \\
\text { and DOE. (See Note 1.) }\end{array}$ & $\begin{array}{l}\text { Third of three project reviews required by } \\
\text { TWRS SEMP. }\end{array}$ \\
\hline
\end{tabular}

Note 1: Processes and Products not complete as of April, 1998. 
HNF-2578, Rev. 0

\subsection{BASELINE PRODUCT ROLES AND RESPONSIBILITIES}

Table 3.2 provides a matrix of organizations/positions (internal to PHMC) defined in the Immobilized Low-Activity Waste Disposal Plan (NHC 1997b) and the baseline products identified in section 3.2.2. The matrix indicates several levels of responsibility, including: approval authority, concurrence, review, and preparation lead.

Table 3.2. Roles and Responsibilities Matrix for Major Technical Baseline Products.

\begin{tabular}{|c|c|c|c|c|c|}
\hline & oduct & Approval & Concurrence & Review & $\begin{array}{l}\text { Preparation } \\
\text { Lead }\end{array}$ \\
\hline & 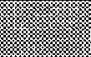 & / & 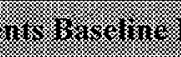 & 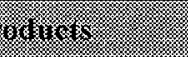 & \\
\hline $\begin{array}{l}\mathrm{AG} \\
\text { Inte }\end{array}$ & $\begin{array}{l}\text { r ILAW } \\
\text { Storage }\end{array}$ & See Note 1. & See Note 1. & See Note 1. & See Note 1 . \\
\hline $\begin{array}{l}\mathrm{D} \\
\mathrm{R}\end{array}$ & $\begin{array}{l}\text { Level } \\
\text { One } \\
\text { Specs }\end{array}$ & $\begin{array}{l}\text { M\&I Contractor } \\
\text { PM }\end{array}$ & $\begin{array}{l}\text { QA } \\
\text { SE } \\
\text { Operations } \\
\text { TE }\end{array}$ & Project Mgr. & Project Engr. \\
\hline D & $\begin{array}{l}\text { Level } \\
\text { Two } \\
\text { Specs }\end{array}$ & N/A & N/A & N/A & N/A \\
\hline $\begin{array}{l}\text { ILA } \\
\text { Plar }\end{array}$ & Disposal & See Note 1. & See Note 1. & See Note 1. & See Note 1. \\
\hline O\& & oncept & $\begin{array}{l}\text { PM } \\
\text { Operations }\end{array}$ & $\begin{array}{l}\mathrm{EQS} \\
\mathrm{TE}\end{array}$ & $\begin{array}{l}\text { Project Engr. } \\
\text { Construct. Rep. } \\
\text { Maintenance }\end{array}$ & $\begin{array}{l}\mathrm{TE} \\
\text { Operations }\end{array}$ \\
\hline $\mathrm{RA}$ & nalysis & $\begin{array}{l}\text { PM } \\
\text { Operations }\end{array}$ & $\mathrm{TE}$ & Construct. Rep. & TE \\
\hline $\begin{array}{l}\text { Pro } \\
\text { Val } \\
\text { Pac }\end{array}$ & & $\begin{array}{l}\text { M\&I Contractor } \\
\text { PM } \\
\text { Project Mgr. }\end{array}$ & Business Mgr. & $\begin{array}{l}\text { TE } \\
\text { EQS } \\
\text { SE } \\
\text { Operations }\end{array}$ & Project Mgr. \\
\hline QA & & $\begin{array}{l}\text { EQS, PM, } \\
\text { Project Mgr. }\end{array}$ & $\begin{array}{l}\mathrm{TE} \\
\text { Operations }\end{array}$ & $\mathrm{SE}$ & EQS \\
\hline $\begin{array}{l}\text { Pre } \\
\text { Saf } \\
\text { Eva }\end{array}$ & ary & See Note 1. & See Note 1. & See Note 1. & See Note 1. \\
\hline
\end{tabular}


HNF-2578, Rev. 0

\begin{tabular}{|l|l|l|l|l|}
\hline \multicolumn{1}{|c|}{ Product } & \multicolumn{1}{|c|}{ Approval } & Concurrence & Review & $\begin{array}{l}\text { Preparation } \\
\text { Lead }\end{array}$ \\
\hline Permitting Plan & $\begin{array}{l}\text { EQS } \\
\text { PM }\end{array}$ & $\begin{array}{l}\text { Project Mgr. } \\
\text { SE }\end{array}$ & $\begin{array}{l}\text { Operations } \\
\text { TE }\end{array}$ & EQS \\
\hline $\begin{array}{l}\text { RCRA Permit } \\
\text { Applications }\end{array}$ & $\begin{array}{l}\text { M\&I } \\
\text { Contractors }\end{array}$ & $\begin{array}{l}\text { PM } \\
\text { Project Mgr. }\end{array}$ & $\begin{array}{l}\text { TE } \\
\text { SE } \\
\text { Operations }\end{array}$ & EQS \\
\hline $\begin{array}{l}\text { Trade Study } \\
\text { Reports }\end{array}$ & $\begin{array}{l}\text { TE } \\
\text { PM }\end{array}$ & $\begin{array}{l}\text { Operations } \\
\text { SE } \\
\text { Project Mgr. }\end{array}$ & $\begin{array}{l}\text { Business Mgr. } \\
\text { QA }\end{array}$ & TE \\
\hline $\begin{array}{l}\text { ICDs between W- } \\
\text { 465 and } \\
\text { Privatization } \\
\text { Vendors }\end{array}$ & $\begin{array}{l}\text { M\&I } \\
\text { Contractors }\end{array}$ & $\begin{array}{l}\text { EQS } \\
\text { TE } \\
\text { Project Mgr. }\end{array}$ & $\begin{array}{l}\text { SE } \\
\text { Operations Rep. }\end{array}$ & \\
\hline $\begin{array}{l}\text { Infrastructure } \\
\text { ICDs }\end{array}$ & $\begin{array}{l}\text { M\&I } \\
\text { Contractors } \\
\text { Program Mgr. }\end{array}$ & $\begin{array}{l}\text { TE } \\
\text { EQS } \\
\text { Project Mgr. }\end{array}$ & $\begin{array}{l}\text { Operations } \\
\text { Business Mgr. }\end{array}$ & Project Mgr. \\
\hline $\begin{array}{l}\text { Contract } \\
\text { Documents } \\
\text { for Programmatic } \\
\text { Agreements } \\
\text { between } \\
\text { Contractors }\end{array}$ & $\begin{array}{l}\text { M\&I Contractor } \\
\text { Program Mgr. }\end{array}$ & $\begin{array}{l}\text { Business Mgr. } \\
\text { TE } \\
\text { SE } \\
\text { EQS }\end{array}$ & Business Mgr. & Program Mgr. \\
\hline $\begin{array}{l}\text { Transportation } \\
\text { Packaging Design } \\
\text { Criteria }\end{array}$ & $\begin{array}{l}\text { TE } \\
\text { Program Mgr. }\end{array}$ & $\begin{array}{l}\text { Project Mgr. } \\
\text { Operations } \\
\text { EQS }\end{array}$ & SE & \\
\hline $\begin{array}{l}\text { Conceptual } \\
\text { Design Report }\end{array}$ & See Note 1. & See Note 1. & See Note 1. & See Note 1. \\
\hline $\begin{array}{l}\text { Decision } \\
\text { Documents }\end{array}$ & $\begin{array}{l}\text { Project Mgr. } \\
\text { Program Mgr. }\end{array}$ & $\begin{array}{l}\text { TE, Operations, } \\
\text { SE, EQS }\end{array}$ & Business Mgr. & TE \\
\hline
\end{tabular}


HNF-2578, Rev, 0

\begin{tabular}{|c|c|c|c|c|}
\hline Product & Approval & Concurrence & Review & $\begin{array}{c}\text { Preparation } \\
\text { Lead }\end{array}$ \\
\hline \multicolumn{5}{|c|}{ (1.6. } \\
\hline $\begin{array}{l}\text { Project } \\
\text { Management } \\
\text { Plan }\end{array}$ & PM & & $\begin{array}{l}\text { Business Mgr. } \\
\text { Project Engr. } \\
\text { M\&I Contractor } \\
\text { TE, SE, EQS }\end{array}$ & $\mathrm{TE}$ \\
\hline PSAR & $\begin{array}{l}\text { M\&I Contractor } \\
\text { TE } \\
\text { PM }\end{array}$ & $\begin{array}{l}\text { Project Mgr. } \\
\text { Operations }\end{array}$ & $\begin{array}{l}\text { Tier } 1,2,3 \\
\text { SE } \\
\text { EQS }\end{array}$ & $\mathrm{TE}$ \\
\hline SARP & $\begin{array}{l}\text { M\&I Contractor } \\
\text { TE } \\
\text { PM }\end{array}$ & $\begin{array}{l}\text { Project Mgr. } \\
\text { Operations }\end{array}$ & $\begin{array}{l}\text { Tier } 1,2,3 \\
\text { SE } \\
\text { EQS } \\
\text { Packaging Engr. }\end{array}$ & $\begin{array}{l}\text { TE } \\
\text { WMNW }\end{array}$ \\
\hline $\begin{array}{l}\text { ILAW } \\
\text { Transportation/ } \\
\text { Packaging System } \\
\text { Specs }\end{array}$ & $\begin{array}{l}\text { DynCorp } \\
\text { Project Mgr. }\end{array}$ & $\begin{array}{l}\text { Operations } \\
\text { TE, EQS } \\
\text { Project Engr. } \\
\text { SE }\end{array}$ & Business Mgr. & $\begin{array}{l}\text { Project Mgr. } \\
\text { TE }\end{array}$ \\
\hline $\begin{array}{l}\text { W-465 } \\
\text { Preliminary } \\
\text { Design } \\
\text { (Title I) }\end{array}$ & $\begin{array}{l}\text { Program Mgr. } \\
\text { Project Mgr. }\end{array}$ & $\begin{array}{l}\text { TE\&NS } \\
\text { Project Mgr. } \\
\text { Operations }\end{array}$ & $\begin{array}{l}\text { M\&I Contractor } \\
\text { Business Mgr. } \\
\text { SE, EQS }\end{array}$ & $\begin{array}{l}\text { Project Mgr. } \\
\text { Design Agent }\end{array}$ \\
\hline $\begin{array}{l}\text { W-465 } \\
\text { Detailed } \\
\text { Design } \\
\text { (Title II) }\end{array}$ & Project Mgr. & $\begin{array}{l}\text { TE } \\
\text { Operations }\end{array}$ & $\begin{array}{l}\text { Business Mgr. } \\
\text { M\&I Contractor } \\
\text { SE, EQS, } \\
\text { Construct. Rep. }\end{array}$ & $\begin{array}{l}\text { Project Mgr. } \\
\text { Design Agent }\end{array}$ \\
\hline $\begin{array}{l}\text { Master Equipment } \\
\text { List } \\
\text { (MEL) }\end{array}$ & Project Mgr. & $\begin{array}{l}\text { Project Engr. } \\
\text { TE } \\
\text { Operations }\end{array}$ & $\begin{array}{l}\text { SE } \\
\text { Operations } \\
\text { EQS }\end{array}$ & $\begin{array}{l}\mathrm{TE} \\
\text { Design Agent }\end{array}$ \\
\hline $\begin{array}{l}\text { P\&IDs and } \\
\text { Essential } \\
\text { Drawings }\end{array}$ & Project Mgr. & $\begin{array}{l}\text { Operations } \\
\text { TE } \\
\text { Project Engr. }\end{array}$ & $\begin{array}{l}\text { Project Engr. } \\
\text { Construct. Rep. } \\
\text { SE, EQS }\end{array}$ & $\begin{array}{l}\text { Project Mgr. } \\
\text { Design Agent }\end{array}$ \\
\hline
\end{tabular}


HNF-2578, Rev. 0

\begin{tabular}{|l|l|l|l|l|}
\hline \multicolumn{1}{|c|}{ Product } & \multicolumn{1}{|c|}{ Approval } & Concurrence & \multicolumn{1}{|c|}{ Review } & $\begin{array}{l}\text { Preparation } \\
\text { Lead }\end{array}$ \\
\hline $\begin{array}{l}\text { Construction \& } \\
\text { Procurement } \\
\text { Specifications }\end{array}$ & Project Mgr. & $\begin{array}{l}\text { Operations } \\
\text { TE }\end{array}$ & $\begin{array}{l}\text { SE, EQS } \\
\text { Project Engr. } \\
\text { Construct. Rep. } \\
\text { Operations Rep. } \\
\text { Business Rep. }\end{array}$ & $\begin{array}{l}\text { Project Mgr. } \\
\text { Design Agent }\end{array}$ \\
\hline $\begin{array}{l}\text { Test } \\
\text { Procedures }\end{array}$ & Project Mgr. & $\begin{array}{l}\text { Operations } \\
\text { Construct. Rep. } \\
\text { TE } \\
\text { EQS }\end{array}$ & $\begin{array}{l}\text { SE } \\
\text { Construct. Rep. }\end{array}$ & $\begin{array}{l}\text { Project Mgr. } \\
\text { Design Agent }\end{array}$ \\
\hline $\begin{array}{l}\text { Test } \\
\text { Reports }\end{array}$ & Project Mgr. & $\begin{array}{l}\text { Operations } \\
\text { Construct. Rep. } \\
\text { TE } \\
\text { EQS }\end{array}$ & SE & $\begin{array}{l}\text { Project Mgr. } \\
\text { Design Agent }\end{array}$ \\
\hline $\begin{array}{l}\text { Design Analysis } \\
\text { Report }\end{array}$ & Project Mgr. & TE & $\begin{array}{l}\text { Project Mgr. } \\
\text { SE, EQS }\end{array}$ & $\begin{array}{l}\text { Project Mgr } \\
\text { Design Agent }\end{array}$ \\
\hline $\begin{array}{l}\text { Operations } \\
\text { Performance } \\
\text { Assessment (PA) }\end{array}$ & $\begin{array}{l}\text { M\&I Contractor } \\
\text { Program Mgr. }\end{array}$ & EQS & $\begin{array}{l}\text { Program Mgr. } \\
\text { TE } \\
\text { Business Mgr. } \\
\text { SE }\end{array}$ & PA Lead \\
\hline $\begin{array}{l}\text { Waste Form Data } \\
\text { Packages }\end{array}$ & N/A & N/A & PA Lead & PNNL \\
\hline $\begin{array}{l}\text { Geotechnical Data } \\
\text { Packages }\end{array}$ & N/A & N/A & PA Lead & PNNL \\
\hline $\begin{array}{l}\text { Analysis } \\
\text { Fosite }\end{array}$ & & FDNW \\
\hline
\end{tabular}


HNF-2578, Rev. 0

\begin{tabular}{|c|c|c|c|c|}
\hline Product & Approval & Concurrence & Review & $\begin{array}{c}\text { Preparation } \\
\text { Lead }\end{array}$ \\
\hline \multicolumn{5}{|c|}{ 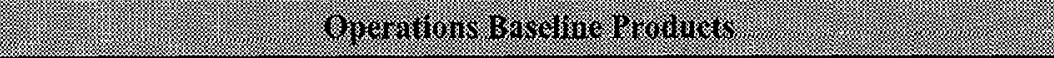 } \\
\hline $\begin{array}{l}\text { FSAR or TWRS } \\
\text { Authorization } \\
\text { Basis Amendment }\end{array}$ & $\begin{array}{l}\text { M\&I Contractor } \\
\text { Program Mgr. }\end{array}$ & $\begin{array}{l}\text { TE } \\
\text { Operations }\end{array}$ & $\begin{array}{l}\text { Tier } 1,2,3 \\
\text { SE } \\
\text { EQS }\end{array}$ & $\mathrm{TE}$ \\
\hline $\begin{array}{l}\text { Safety Equipment } \\
\text { List } \\
\text { (SEL) }\end{array}$ & $\begin{array}{l}\text { Project Mgr. } \\
\text { TE }\end{array}$ & $\begin{array}{l}\text { TE } \\
\text { EQS } \\
\text { Operations }\end{array}$ & Design Agent & $\begin{array}{l}\text { TE } \\
\text { Design Agent }\end{array}$ \\
\hline Job Task Analysis & Program Mgr. & Operations & $\begin{array}{l}\text { Project Mgr. } \\
\text { EQS }\end{array}$ & Operations \\
\hline $\begin{array}{l}\text { Training } \\
\text { Certification } \\
\text { Products }\end{array}$ & Program Mgr. & $\begin{array}{l}\text { TE } \\
\text { Operations }\end{array}$ & $\begin{array}{l}\text { Project Mgr. } \\
\text { SE, EQS }\end{array}$ & Operations \\
\hline $\begin{array}{l}\text { O\&M Manuals } \\
\text { and Procedures }\end{array}$ & $\begin{array}{l}\text { Project Mgr. } \\
\text { Operations }\end{array}$ & $\mathrm{TE}$ & EQS & $\begin{array}{l}\text { Operations } \\
\mathrm{TE}\end{array}$ \\
\hline $\begin{array}{l}\text { Permit and } \\
\text { License } \\
\text { Applications }\end{array}$ & $\begin{array}{l}\text { M\&I Contractor } \\
\text { PM }\end{array}$ & $\begin{array}{l}\text { EQS } \\
\text { Project Mgr. } \\
\text { Operations }\end{array}$ & $\begin{array}{l}\text { SE } \\
\text { TE }\end{array}$ & $\mathrm{EQS}$ \\
\hline As-Built Drawings & $\begin{array}{l}\text { Project Mgr. } \\
\text { TE }\end{array}$ & $\begin{array}{l}\text { Operations } \\
\text { Construct. Rep. } \\
\text { Design Agent }\end{array}$ & $\begin{array}{l}\text { EQS } \\
\text { Operations }\end{array}$ & $\begin{array}{l}\text { Project Engr. } \\
\text { Design Agent }\end{array}$ \\
\hline \multicolumn{5}{|c|}{ 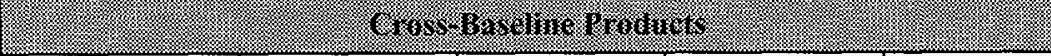 } \\
\hline T\&E Plan & Program Mgr. & $\begin{array}{l}\text { Project Mgr. } \\
\text { SE, EQS } \\
\text { Operations } \\
\text { TE } \\
\end{array}$ & $\begin{array}{l}\text { Project Engr. } \\
\text { Business Mgr. }\end{array}$ & Project Mgr. \\
\hline SEMIP & Program Mgr. & $\begin{array}{l}\text { Project Mgr. } \\
\text { TE } \\
\text { SE }\end{array}$ & $\begin{array}{l}\text { Operations. } \\
\text { EQS }\end{array}$ & $\mathrm{SE}$ \\
\hline $\begin{array}{l}\text { Level } 1 \text { Logic } \\
\text { Diagrams }\end{array}$ & Program Mgr. & $\begin{array}{l}\text { Project Mgr. } \\
\text { TE } \\
\text { Operations } \\
\text { SE }\end{array}$ & EQS & Project Engr. \\
\hline
\end{tabular}


HNF-2578, Rev. 0

\begin{tabular}{|l|l|l|l|l|}
\hline \multicolumn{1}{|c|}{ Product } & \multicolumn{1}{|c|}{ Approval } & Concurrence & \multicolumn{1}{c|}{ Review } & $\begin{array}{l}\text { Preparation } \\
\text { Lead }\end{array}$ \\
\hline $\begin{array}{l}\text { HSTD Change } \\
\text { Requests }\end{array}$ & Project Mgr. & $\begin{array}{l}\text { SE } \\
\text { TE }\end{array}$ & $\begin{array}{l}\text { Project Engr. } \\
\text { EQS }\end{array}$ & SE \\
\hline $\begin{array}{l}\text { Risk Management } \\
\text { List }\end{array}$ & $\begin{array}{l}\text { Program Mgr. } \\
\text { Project Mgr. }\end{array}$ & $\begin{array}{l}\text { TE } \\
\text { SE } \\
\text { EQS } \\
\text { Operations }\end{array}$ & $\begin{array}{l}\text { Program Mgr. } \\
\text { Project Mgr. }\end{array}$ & $\begin{array}{l}\text { Program Mgr. } \\
\text { Project Mgr. }\end{array}$ \\
\hline
\end{tabular}

Note 1. Product completed at time of writing.

Legend: TE: TWRS Engineering and Nuclear Safety

EQS: Environmental, Quality, and Safety

PM: Program Manager/Engineer

M\&I: Management and Integration

SE: Systems Engineering

QA: Quality Assurance

PNNL: Pacific Northwest National Laboratory

FDNW: Flour-Daniel Northwest

PA: Performance Assessment 


\subsection{REFERENCES}

DOE, 1995, Life-Cycle Asset Management, DOE Order 430.1, U.S. Department of Energy,

Washington, D. C.

DOE, 1996a, Letter, from W. J. Taylor, DOE, to President, Westinghouse Hanford Company, Milestone Completion, Issue Low-Level Waste Interim Storage Engineering Evaluation, 96-WDD-149, September 27, 1996, Westinghouse Hanford Company, Richland, Washington.

DOE, 1996b, Tank Waste Remediation System, Hanford Site, Final Environmental Impact Statement, DOE/EIS-0189, U.S. Department of Energy, Washington, D. C.

DOE-RL, 1996a, TWRS Privatization Contract No. DE-RP06-96RL13308, Contract with British Nuclear Fuels Ltd., U.S. Department of Energy, Richland, Operations Office, Richland, Washington.

DOE-RL, 1996b, TWRS Privatization Contract No. DE-RP06-96RL13309, Contract with Lockheed Martin Advanced Environmental Systems, U.S. Department of Energy, Richland, Operations Office, Richland, Washington,

DOE-RL, 1996c, Letter from A. L. Alm to Manager, DOE Richland Operations Office, Approval of Critical Decisions for Phase I Immobilized High-Level and Low-Activity Waste Interim Storage and Tank Farm Restoration and Safe Operations Projects (Projects W-464, W465, and $W$-314), December 26, 1996, Department of Energy, Richland Operations Office, Richland, Washington.

Federal Register, 1997, Record of Decision for the Tank Waste Remediation System, Hanford Site, Richland Washington, Federal Register Vol. 62, No. 38, Feb. 1997.

FDH, 1997a, Configuration Management Plan,HNF-MP-013, Rev 0, Fluor Daniel Hanford Corporation, Richland, Washington.

FDH, 1997b, Draft Interface Control Document between DOE and the PHMC Phase I

Privatization - Immobilized Low-Activity Waste Procedures, Lockheed Martin Hanford Corporation for Fluor Daniel Hanford Company, Richland, Washington

FDH, 1997d, Quality Assurance Program Description, HNF-MP-599, Flour-Daniel Hanford Corporation, Richland, Washington. (http://docs.rl.gov/phpp/mp-599ro.htm)

FDH, 1998a, Tank Waste Remediation System Risk Management Plan, HNF-SD-WM-PMP-018, Rev 2, prepared by Lockheed Martin Hanford Corporation for Fluor Daniel Hanford, Inc., Richland, Washington. 
HNF-2578, Rev. 0

FDH, 1998b, Tank Waste Remediation System Retrieval and Disposal Mission Technical Baseline Description, HNF-1901, Rev 0, prepared by Lockheed Martin Hanford Corporation for Fluor Daniel Hanford, Inc., Richland, Washington.

FDH, 1998c, TWRS Retrieval and Disposal Mission Key Enabling Assumptions, HNF-1945, Fluor Daniel Hanford, Inc., Richland, Washington.

FDH, 1998d, Tank Waste Remediation System Configuration Management Plan, HNF-1900, Flour Daniel Hanford Corp., Richland WA.

FDH, 1998e, Tank Waste Remediation System Program Plan, HNF-1883, Rev. 1, Flour Daniel Hanford Corp., Richland, WA.

FDNW, 1997a, Immobilized Low-Activity Waste Interim Storage Facility Project W-465 Conceptual Design Report, HNF-1975, Fluor Daniel Northwest, Inc. Richland, Washington.

Lerch, 1997, R. E. Lerch, Team Leader, Independent Review Team, Tank Waste Retrieval Readiness-To-Proceed Independent Review Team Final Report, December, 1997.

LMHC, 1997a, TWRS Change Control, LMH-MD-004, Rev 0, Lockheed Martin Hanford Corporation, Richland, Washington.

LMHC, 1997b, Tank Waste Remediation System Administrative Manual, HNF-IP-0842, Lockheed Martin Hanford Corporation, Richland, Washington.

LMHC, 1997c, Permitting Plan for the Immobilized Low-Activity Waste Project, HNF-SD-ENVEE-003, Rev 0, Lockheed Martin Hanford Corporation, Richland, Washington.

LMHC, 1997d, Tank Waste Remediation System Operations and Utilization Plan, HNF-SD-IPSP-012, Rev 0, Lockheed Martin Hanford Corporation, Richland, Washington.

LMHC, 1997e, Letter from J. A. Voogd, LMHC, to A. M. Umek, FDH, Subcontract Number 80232764-9-K001, Facilities Safety Board Recommendation 92-4 Implementation Plan, Revision 2N, Commitment 5.2.2(d), 9759192, October 6, 1997, Lockheed Martin Hanford Corporation, Richland, Washington.

LMHC 1997f, Tank Waste Remediation System Configuration Mnagement Implementation Plan, HNF-SD-WM-CM-0014, Lockheed Martin Hanford Corporation, Richland, Washington.

LMHC, 1998a, Tank Waste Remediation System Systems Engineering Management Plan, HNFSD-WM-SEMP, 002, Rev 1, Lockheed Martin Hanford Corporation, Richland, Washington.

LMHC, 1998b, Tank Waste Remediation System Mission Analysis Report, HNF-SD-WM-MAR008, Rev 3, Lockheed Martin Hanford Corporation, Richland, Washington. 
LMHC, 1998d, Memorandum from Interface Control, LHMC, to R. D. Wojtasek, Identification and Control of TWRS Interfaces, 73600-97-PSS-001, Reissued January 7, 1998, Lockheed Martin Hanford Corporation, Richland, Washington.

LMHC, 1998e, Tank Waste Remediation System Engineering Plan, HNF-1947, Rev 0, Lockheed Martin Hanford Corporation, Richland, Washington.

LMHC, 1998f, TWRS Retrieval and Disposal Project Critical Risk Management List, updated monthly, Lockheed Martin Hanford Corporation, Richland, Washington.

LMHC, 1998h, TWRS Retrieval and Disposal Project Risk Management List, (in electronic format, updated monthly).

LMHC, 1998i, Tank Waste Remediation System Test and Evaluation Plan, HNF-2029.

LMHC, 1988j, TWRS Technical Baseline Database Manager Definition Document, HNF-SDTWR-CSUD-001, Aug. 1997.

LMSI, 1995, Documents and Records Management Manual, Lockheed Martin Services, Inc.

Mann, F. M., et al., 1997, Hanford Low-level Tank Waste Interim Performance Assessment, HNF-EP-0884 Rev. 1, September 1997.

Mann, F. M., et al. 1998, Hanford Low-Activity Tank Waste Performance Assessment, DOERL-97-69, Rev. 0, March 1998.

Mouette, P., 1998, Master Safety Plan for Immobilized Low-Activity and High-Level Waste, HNF-2515 (Draft, April 1998).

NHC, 1997a, Preliminary Safety Evaluation for Project W-465, Immobilized LowActivity Waste Interim Storage, HD-SD-W465-PSE-001, Rev 0, Numatec Hanford Corporation, Richland, Washington.

NHC, 1997b, TWRS Retrieval and Disposal Mission, Immobilized Low-Activity Waste Disposal Plan, HNF-1517, Rev 0, Numatec Hanford Corporation, Richland, Washington.

NRC, 1997, Letter from C. J. Paperiello, U.S. Nuclear Regulatory Commission, to J. E Kinzer, U. S. Department of Energy, Classification of Hanford Low-Activity Tank Waste Fraction, dated June 8, 1997, U. S. Nuclear Regulatory Commission, Washington, D. C.

Parsons, 1998a, TWRS Project W-465 Systems Engineering Implementation Assessment Report, Rev 1, Parsons Infrastructure and Technology Group, Inc.,Richland, Washington.

Piper, 1996, Piper, L. L., Justification of Mission Need, Initial Phase I Immobilized Low-Activity Waste Interim Storage, November 27, 1996. 
SESC, 1997, Design Requirements Document for Project W-465, Immobilized Low-Activity Waste Interim Storage, HNF-SD-W465-DRD-001 Rev. 0, SGN Eurisys Services Corporation, Richland, Washington.

SESC, 1998a, Design Requirements Document for Project W-465, Immobilized Low-Activity Waste Interim Storage, HNF-SD-W465-DRD-001 Rev. 1, SGN Eurisys Services Corporation, Richland, Washington.

SESC, 1998b, Phase 1 Immobilized Low Activity Waste Operational Source Term Report, HNF2110.

WHC, 1995a, Letter from R. J. Murkowski, WHC, to P.E. LaMont, Functional Requirements Immobilized Low-Level Waste Interim Storage, 9556303, November 29, 1995.

Westinghouse Hanford Company, Richland, Washington.

WHC, 1995b, Letter from R. J. Murkowski, WHC, to J. D. Thomson, WHC, Storage and Disposal Project Risk Management Plan, 73300-95-011, December 29, 1995, Westinghouse Hanford Company, Richland, Washington.

WHC, 1996a, Alternatives Generation and Analysis Report for Immobilized Low-Level Waste Interim Storage Architecture, WHC-SD-W465-AGA-001, Westinghouse Hanford Company, Richland, Washington.

WHC, 1996c, Letter from R. J. Murkowski to P. E. LaMont, Immmobilized Low-Level Waste Interim Storage Alternatives, 960431, January 30, 1996, Westinghouse Hanford Company, Richland, Washington.

WHC, 1996d, Letter from D. J. Washenfelder to R. J. Murkowski, Immobilized Low-Level Waste Interim Storage Architecture Selection Decision Plan, 9652215, May 15, 1996, Westinghouse Hanford Company, Richland, Washington. 
HNF-2578, Rev. 0

\section{Appendix A}

\section{Project W-465 Systems Engineering}

Graded Assessment Tables 
Table A.1. Systems Engineering Graded Assessment of ILAW Vaults and Equipment.

\begin{tabular}{|c|c|c|c|c|c|}
\hline \multirow{2}{*}{\begin{tabular}{|c|} 
RISKJ \\
COMPLEXITY \\
FACTOR \\
\end{tabular}} & \multirow{2}{*}{ ASSESSMENT } & \multicolumn{3}{|c|}{ RISK } & \multirow{2}{*}{ COMMENTS } \\
\hline & & $L$ & $M$ & $\mathrm{H}$ & \\
\hline Technology & $\begin{array}{l}\text { Common technology and } \\
\text { conventional } \\
\text { construction. }\end{array}$ & $\mathrm{x}$ & & & $\begin{array}{l}\text { Standard civil construction } \\
\text { application required. }\end{array}$ \\
\hline Time & $\begin{array}{l}\text { Compressed time frame } \\
\text { to perform work. }\end{array}$ & & & $x$ & $\begin{array}{l}\text { May be greatest source of } \\
\text { Project risk. }\end{array}$ \\
\hline Interfaces & $\begin{array}{l}\text { Potential impact on site } \\
\text { operations, other } \\
\text { contractors, projects, } \\
\text { programs, etc. }\end{array}$ & & $\mathrm{X}$ & & $\begin{array}{l}\text { Several high-level } \\
\text { interfaces between } \\
\text { participants. }\end{array}$ \\
\hline $\begin{array}{l}\text { Number of Key } \\
\text { Participants }\end{array}$ & 3 or more & & & $x$ & $\begin{array}{l}\text { Several Hanford Site } \\
\text { contractors plus two private } \\
\text { vendors. }\end{array}$ \\
\hline $\begin{array}{l}\text { Contractor } \\
\text { Capabilities }\end{array}$ & Proven track record & $x$ & & & $\begin{array}{l}\text { Disposal facility } \\
\text { construction capability risk } \\
\text { is low. }\end{array}$ \\
\hline $\begin{array}{l}\text { Magnitude and Type } \\
\text { of Environmental } \\
\text { Contamination }\end{array}$ & $\begin{array}{l}\text { Hazardous or low-level } \\
\text { waste, fully characterized }\end{array}$ & $\mathrm{X}$ & & & $\begin{array}{l}\text { Waste will be fully } \\
\text { characterized and in a } \\
\text { sealed, solid form on receipt } \\
\text { by the project. }\end{array}$ \\
\hline $\begin{array}{l}\text { Regulatory } \\
\text { Involvement }\end{array}$ & EPA, NRC, or States & & $\mathrm{X}$ & & $\begin{array}{l}\text { EPA and WA State } \\
\text { involvement. }\end{array}$ \\
\hline $\begin{array}{l}\text { Environmental } \\
\text { Permits (RCRA, } \\
\text { CWA, CAA, etc.) or } \\
\text { Licensing }\end{array}$ & $\begin{array}{l}\text { Environmental } \\
\text { Assessment, EIS, or } \\
\text { unique permitting } \\
\text { required }\end{array}$ & $x$ & $\mathrm{X}$ & & $\begin{array}{l}\text { EIS complete and Record of } \\
\text { Decision issued. } \\
\text { RCRA permitting } \\
\text { anticipated. Other permit } \\
\text { waivers or deviations may } \\
\text { be necessary. }\end{array}$ \\
\hline
\end{tabular}


HNF-2578, Rev. 0

\begin{tabular}{|c|c|c|c|c|c|}
\hline \multirow{2}{*}{\begin{tabular}{|c|} 
RISK/ \\
COMPLEXITY \\
FACTOR \\
\end{tabular}} & \multirow[t]{2}{*}{ ASSESSMENT } & \multicolumn{3}{|c|}{ RISK } & \multirow[t]{2}{*}{ COMMENTS } \\
\hline & & $\mathrm{L}$ & $M$ & $\mathrm{H}$ & \\
\hline $\begin{array}{l}\text { Number of Locations } \\
\text { Site Ownership } \\
\text { Site Improvement/ } \\
\text { Access }\end{array}$ & $\begin{array}{l}1 \\
\text { DOE property } \\
\text { Minor infrastructure/ } \\
\text { improvements required } \\
\text { and accessible. }\end{array}$ & $\begin{array}{l}x \\
x\end{array}$ & & & $\begin{array}{l}\text { Single location for vault } \\
\text { facility, on DOE site. } \\
\text { Disposal site is DOE } \\
\text { owned. } \\
\text { Risk and complexity of site } \\
\text { improvements is low. }\end{array}$ \\
\hline $\begin{array}{l}\text { Labor Skills } \\
\text { Availability } \\
\text { Staff Build-Up } \\
\text { Productivity }\end{array}$ & $\begin{array}{l}\text { Low or moderate skill } \\
\text { labor } \\
\text { Readily available } \\
\text { Gradual } \\
\text { Low or average } \\
\text { productivity assumed }\end{array}$ & $\begin{array}{l}x \\
x \\
X \\
X\end{array}$ & & & $\begin{array}{l}\text { Project management and } \\
\text { design teams are in place. } \\
\text { Construction contractors are } \\
\text { readily available. }\end{array}$ \\
\hline $\begin{array}{l}\text { Quality } \\
\text { Requirements }\end{array}$ & $\begin{array}{l}\text { Large quality tolerances } \\
\text { and low productivity risk }\end{array}$ & $\mathrm{X}$ & & & $\begin{array}{l}\text { Project risk assumed for } \\
\text { waste quality is low. } \\
\text { Quality risk for disposal } \\
\text { facility construction is also } \\
\text { low. }\end{array}$ \\
\hline Funding & 2 or more year duration. & & $\mathrm{X}$ & & $\begin{array}{l}\text { Although funding must be } \\
\text { maintained over a } \\
\text { significant period, risk is } \\
\text { moderate within Hanford } \\
\text { site context. }\end{array}$ \\
\hline Political Visibility & Major & $\mathrm{X}$ & & & $\begin{array}{l}\text { Political visibility is high, } \\
\text { but the associated risk to the } \\
\text { Project is low. }\end{array}$ \\
\hline Cost Sharing & None & $\mathrm{X}$ & & & None required. \\
\hline Public Involvement & Minor & $\mathrm{X}$ & & & $\begin{array}{l}\text { Public input is expected to } \\
\text { have a positive effect on the } \\
\text { Project. }\end{array}$ \\
\hline
\end{tabular}


HNF-2578, Rev. 0

\begin{tabular}{|c|c|c|c|c|c|}
\hline \multirow{2}{*}{$\begin{array}{c}\text { RISK/ } \\
\text { COMPLEXITY } \\
\text { FACTOR }\end{array}$} & \multirow[t]{2}{*}{ ASSESSMENT } & \multicolumn{3}{|c|}{ RISK } & \multirow[t]{2}{*}{ COMMENTS } \\
\hline & & $\mathrm{L}$ & $\mathrm{M}$ & $\mathrm{H}$ & \\
\hline $\begin{array}{l}\text { OVERALL } \\
\text { COMPLEXITY }\end{array}$ & $\begin{array}{l}\text { Low technology level for } \\
\text { construction, several key } \\
\text { participants, compressed } \\
\text { time frame, moderate } \\
\text { permitting and funding } \\
\text { risk. }\end{array}$ & $\mathrm{X}$ & & & $\begin{array}{l}\text { Low risk/complexity results } \\
\text { in an SE Level } 2 \\
\text { application: a selective } \\
\text { application of systems } \\
\text { engineering. }\end{array}$ \\
\hline
\end{tabular}


HNF-2578, Rev. 0

Table A.2. Systems Engineering Graded Assessment of ILAW Transport/Packaging Systems.

\begin{tabular}{|c|c|c|c|c|c|}
\hline \multirow{2}{*}{$\begin{array}{c}\text { RISK/ } \\
\text { COMPLEXITY } \\
\text { FACTOR }\end{array}$} & \multirow[t]{2}{*}{ ASSESSMENT } & \multicolumn{3}{|c|}{ RISK } & \multirow[t]{2}{*}{ COMMENTS } \\
\hline & & $L$ & M & $\mathrm{H}$ & \\
\hline Technology & Common technology. & $\mathrm{X}$ & & & $\begin{array}{l}\text { Little technology risk or } \\
\text { complexity. }\end{array}$ \\
\hline Time & $\begin{array}{l}\text { Ample time to perform } \\
\text { work. }\end{array}$ & $\mathrm{X}$ & & & Not a critical path system. \\
\hline Interfaces & $\begin{array}{l}\text { No major impact on site } \\
\text { operations, other } \\
\text { contractors, projects, } \\
\text { programs, etc. }\end{array}$ & $\mathrm{X}$ & & & $\begin{array}{l}\text { Interfaces involve ILAW } \\
\text { storage/disposal facility, } \\
\text { PCS, and Waste } \\
\text { Management Hanford. }\end{array}$ \\
\hline $\begin{array}{l}\text { Number of Key } \\
\text { Participants }\end{array}$ & $2-3$ & & $X$ & & $\begin{array}{l}\text { Several key participants for } \\
\text { design, project } \\
\text { management, fabrication } \\
\text { and construction. }\end{array}$ \\
\hline $\begin{array}{l}\text { Contractor } \\
\text { Capabilities }\end{array}$ & Proven track record & $x$ & & & $\begin{array}{l}\text { Experienced contractors } \\
\text { involved. }\end{array}$ \\
\hline $\begin{array}{l}\text { Magnitude and Type } \\
\text { of Environmental } \\
\text { Contamination }\end{array}$ & $\begin{array}{l}\text { Hazardous or low-level } \\
\text { waste, fully } \\
\text { characterized. }\end{array}$ & $\mathrm{X}$ & & & $\begin{array}{l}\text { Waste will be fully } \\
\text { characterized and in solid, } \\
\text { sealed form on receipt by } \\
\text { Project. }\end{array}$ \\
\hline $\begin{array}{l}\text { Regulatory } \\
\text { Involvement }\end{array}$ & None & $\mathrm{X}$ & & & $\begin{array}{l}\text { On site shipment under } \\
\text { Hanford site procedures. } \\
\text { No DOT or NRC approval } \\
\text { required. }\end{array}$ \\
\hline $\begin{array}{l}\text { Environmental } \\
\text { Permits (RCRA, } \\
\text { CWA, CAA, etc.) or } \\
\text { Licensing }\end{array}$ & No permitting & $\mathrm{X}$ & & & $\begin{array}{l}\text { Standard construction } \\
\text { documentation required: } \\
\text { storm water pollution } \\
\text { prevention, environmental } \\
\text { checklist, etc. } \\
\text { SARP satisfies permitting } \\
\text { requirements. }\end{array}$ \\
\hline
\end{tabular}


HNF-2578, Rev. 0

\begin{tabular}{|c|c|c|c|c|c|}
\hline \multirow{2}{*}{$\begin{array}{c}\text { RISK/ } \\
\text { COMPLEXITY } \\
\text { FACTOR } \\
\end{array}$} & \multirow[t]{2}{*}{ ASSESSMENT } & \multicolumn{3}{|c|}{ RISK } & \multirow{2}{*}{ COMMENTS } \\
\hline & & L & M & $\mathrm{H}$ & \\
\hline $\begin{array}{l}\text { Number of Locations } \\
\text { Site Ownership } \\
\text { Site Improvement/ } \\
\text { Access }\end{array}$ & 1 & $\begin{array}{l}x \\
x\end{array}$ & & & $\begin{array}{l}\text { Single site } \\
\text { DOE Property } \\
\text { N/A }\end{array}$ \\
\hline $\begin{array}{l}\text { Labor Skills } \\
\text { Availability } \\
\text { Staff Build-Up } \\
\text { Productivity }\end{array}$ & $\begin{array}{l}\text { Low or moderately } \\
\text { skilled labor } \\
\text { Labor readily available } \\
\text { None required } \\
\text { Low or average } \\
\text { productivity assumed } \\
\text { and moderate schedule } \\
\text { risk. }\end{array}$ & $\begin{array}{l}x \\
x \\
x \\
x\end{array}$ & & & $\begin{array}{l}\text { Required for shipping } \\
\text { container fabrication. } \\
\text { Vendor will produce } \\
\text { vehicles and shipping } \\
\text { containers for transport } \\
\text { system. }\end{array}$ \\
\hline $\begin{array}{l}\text { Quality } \\
\text { Requirements }\end{array}$ & $\begin{array}{l}\text { Large quality tolerances } \\
\text { and low productivity } \\
\text { risk. }\end{array}$ & $\mathrm{x}$ & & & $\begin{array}{l}\text { Shipping container quality } \\
\text { requirements are minimal. }\end{array}$ \\
\hline Funding & 2 or more year duration & & $x$ & & $\begin{array}{l}\text { Funding must be } \\
\text { maintained over a } \\
\text { significant period, but } \\
\text { associated risk is moderate. }\end{array}$ \\
\hline Political Visibility & Minor & $x$ & & & $\begin{array}{l}\text { Little risk associated with } \\
\text { transport system. }\end{array}$ \\
\hline Cost Sharing & & & & & N/A \\
\hline Public Involvement & None & $\mathrm{x}$ & & & $\begin{array}{l}\text { Little or no public } \\
\text { involvement with on site } \\
\text { transport and packaging. }\end{array}$ \\
\hline
\end{tabular}


HNF-2578, Rev. 0

\begin{tabular}{|c|c|c|c|c|c|}
\hline \multirow{2}{*}{$\begin{array}{c}\text { RISK/ } \\
\text { COMPLEXITY } \\
\text { FACTOR }\end{array}$} & \multirow[t]{2}{*}{ ASSESSMENT } & \multicolumn{3}{|c|}{ RISK } & \multirow[t]{2}{*}{ COMMENTS } \\
\hline & & L & $\mathrm{M}$ & $\mathrm{H}$ & \\
\hline $\begin{array}{l}\text { OVERALL } \\
\text { COMPLEXITY }\end{array}$ & $\begin{array}{l}\text { Transport/packaging } \\
\text { requirements and } \\
\text { architecture are similar to } \\
\text { other Hanford systems. }\end{array}$ & $X$ & & & $\begin{array}{l}\text { Low risk/complexity results } \\
\text { in an SE Level } 2 \\
\text { application: a selective } \\
\text { application of systems } \\
\text { engineering. }\end{array}$ \\
\hline
\end{tabular}




\section{DISTRIBUTION SHEET}

\begin{tabular}{l|l|l}
\hline To & From & Page 1 of 1 \\
Distribution & Immobilized Waste & Date $4 / 15 / 98$ \\
\hline Project Title/Work Order & EDT No. 621690 \\
\cline { 2 - 2 } $\begin{array}{l}\text { Systems Engineering Management and Implementation Plan for } \\
\text { Project W-465, Immobilized Low-Activity Waste Storage }\end{array}$ & ECN No. \\
\hline
\end{tabular}

\begin{tabular}{c|l|c|c|c|c}
\hline Name & MSIN & $\begin{array}{c}\text { Text } \\
\text { With All } \\
\text { Attach. }\end{array}$ & Text Only & $\begin{array}{c}\text { Attach./ } \\
\text { Appendix } \\
\text { Only }\end{array}$ & $\begin{array}{c}\text { EDT/ECN } \\
\text { Only }\end{array}$ \\
\hline
\end{tabular}

Cogema Engineering Corporation

D. A. Burbank

R. B. Calmus

H6-37

H6-37

$x$

Fluor Daniel Northwest, Inc.

T. A. Carlson

H6-37

T3-06

D. R. Ellingson

B4-43

F. M. Mann

$\mathrm{H} 6-37$

J. B. Payne

H6-37

W. W. Pickett

J. L. Ruud

G3-14

$X$
$X$

Lockheed Martin Hanford Corporation

K. C. Burgard

J. F. Bores

H. L. Boston

D. L. Burt

S. M. Byers

P. A. Craig

M. L. Deffenbaugh

R. J. Murkowski

S. M. O'Toole

L. G. Peck

S. H. Rifaey

R. W. Root

P. S. Schaus

W. T. Thompson

J. A. Voogd

$\begin{array}{ll}H 6-37 & X \\ G 3-21 & X \\ G 3-21 & X \\ G 3-21 & X \\ \text { S1-57 } & X \\ G 3-21 & X \\ H 6-37 & X \\ H 6-37 & X \\ G 3-21 & X \\ H 7-06 & X \\ \text { R1-56 } & X \\ H 6-12 & X \\ H 5-03 & X \\ G 3-21 & X \\ H 6-37 & X\end{array}$

Lockheed Martin Services, Inc.

\section{Project Files (2)}

Central Files

$\begin{array}{ll}H 6-08 & X \\ B 1-07 & X\end{array}$

Numatec Hanford Corporation

J. N. ATibert

$\mathrm{S} 2-48 \quad \mathrm{X}$

P. R. Angelier

$57-82$

M. Cremonini

H5-61

P. Mouette

Rl-49

C. A. Petersen

H6-37

$X$
$X$
$X$
$X$
$X$
$X$

Waste Management Federal Services of Hanford, Inc.

J. E. Mercado

J. G. Riddelle

H1-15

H6-06 